\title{
TÜRK HUKUK YARGILAMASI ILLE MUKAYESELI OLARAK AMERİKAN HUKUK YARGILAMASINDA GIYAPTA HÜKÜM (DEFAULT JUDGMENT)
}

\author{
Mustafa GÖKSU*
}

\begin{abstract}
$\ddot{O} Z$
Bir dava açıldiğında davalının dava dilekçesine cevap vermesinin ya da bir savunmayapmasınınzorunluolup olmadı ̆̆l, hukukyargılamasındakien kilitkonulardan birini oluşturmaktadır. Zira böyle bir zorunluluğun bulunup bulunmadığı hususu, yargılamanın yürütülmesine ilişkin diğer bazı önemli kuralları da etkilemektedir. Keza taraflardan birisinin duruşmalara katılmamasının sonuçları da benzer şekilde büyük önem taşımaktadır. Amerikan hukuk yargılamasında, davaya cevap vermeyen veya yargılamaya katılmayan ya da duruşmalara hazırlık aşamasında mahkemece verilen talimatlara uymayan taraflar bakımından gıyapta hüküm verilmesi usulü bulunmaktadır. Hukukumuzda ise davaya cevap verme zorunluluğu bulunmadı̆̆ gibi, duruşmaya katılmayan taraf bakımından gıyap gibi bir yaptırım da yer almamaktadır. Oysaki glyapta yargılama kurumu, 1985 yılından önce çok uzunca bir süre Türk hukuk yargılamasında var olmuş, ancak karmaşık yapısı ve yeterince anlaşılamamış olması sebebiyle kaldırılmıştır. Bu çalışmada Amerikan hukukundaki gıyapta hüküm kurumu, Türk hukukundaki mevcut hükümler ve mülga glyapta yargllama kurumu ile mukayeseli olarak incelenmiştir.
\end{abstract}

Anahtar Kelimeler: Glyapta yargılama, glyapta hüküm, duruşmalara katılmama, savunma hakkı, davalının davaya cevap vermesi.

\section{DEFAULT JUDGMENT IN AMERICAN CIVIL PROCEDURE IN COMPARISON WITH TURKISH CIVIL PROCEDURE}

\section{ABSTRACT}

The question on whether the defendant is required to present an answer or defend their case is one of the most important matters in civil procedure since this matter directly influence other relevant rules. Similarly, the consequences of absence of a party from proceedings also carry a vital importance. Default judgment is an

* Dr. Öğr. Üyesi, Ankara Hacı Bayram Veli Üniversitesi, Hukuk Fakültesi, Medeni Usul ve İcra - Ifflas Hukuku Anabilim Dalı / ANKARA e-posta: mustafa.goksu@hbv.edu.tr

ORCID: 0000-0003-3414-1699

DOI : 10.34246/ahbvuhfd.1018654

Yayın Kuruluna Ulaştığı Tarih

:21/10/2021

Yayınlanmasının Uygun Görüldü̈̆̈̈ Tarih: 26/10/2021 
institute in American law which is applied to a party who failed to respond to an action, proceedings or a court order regarding pre-trial procedures. In contrast, Turkish law neither compels the defendant for an answer nor provides an institution such as default for the absentee party. Whereas a similar procedure in Turkish law was implemented and utilized for a very long period until 1985; yet it was abolished due to its complex nature and the general misunderstanding regarding the institution. In this article, default judgment in American civil procedure is examined in comparison with the contemporary rules in Turkish civil procedure as well as the now defunct proceedings in default.

Keywords: Proceedings in default, default judgment, absence in trial, right to defend, defendant's response.

\section{GíRIŞ}

Türk hukuk yargılamasında, 1086 sayılı Hukuk Usulü Muhakemeleri Kanunundaki (HUMK) haliyle, 1985 yılında 3156 sayılı Kanunla ilga edilene kadar yaklaşık altmış yıl boyunca uygulanan gıyapta yargılama kurumu yerini, şu anda büyük ölçüde 6100 sayılı Hukuk Muhakemeleri Kanunu'nda (HMK) da yer bulan hükümlere bırakmıştır. Bu çerçevede, davalının davaya cevap vermesinin zorunlu olup olmadığ 1 ve taraflardan birisinin davaya devam etmekten kaçınması halinde ne gibi yaptırımlar uygulanabileceği hususları büyük ölçüde değişime uğramıştır. Türk hukukunda, daha sonra anlatacağımız üzere, davalının davaya cevap vermesi veya duruşmalara katılması, özü itibariyle bir zorunluluk olmaktan çıkmıştır. Zira 6100 sayılı Hukuk Muhakemeleri Kanunu'nun 128'inci maddesi hükmü, davaya cevap verilmemiş olması haline, hiçbir tereddüte yer vermeyecek şekilde inkâr sonucunu bağlamıştır. Keza, artık gıyap kurumu olmadığı için, duruşmalara katılmama halinde de yargılamanın geri kalanı bakımından herhangi bir yaptırım söz konusu olmamaktadır. Oysaki, Almanya ve İngiltere gibi pek çok ülkede olduğu gibi, Amerika Birleşik Devletleri’nde de hukuk yargılamasında, davalının davaya cevap vermesi bir yükümlülük olarak kabul edilmekte; bu yükümlülüğe uyulmaması halinde ise davacının iddialarının ikrarı sonucu doğmaktadır. Bu sayede, boşu boşuna yargılama yapılarak, gereksiz zaman ve gider harcanması engellenmekte; ayrıca davalının bu ihmalkâr davranışı da bir nevi cezalandırılmış olmaktadır. Benzer bir durum taraflardan birisinin duruşmalara geçerli bir mazeret olmaksızın katılmaması halinde de söz konusu olabilmekte; hatta bazı durumlarda mahkemenin emirlerine uymaktan 
haksız şekilde kaçınma da yine aynı yaptırım ile cezalandırılabilmektedir. Çekişmeli yargılamanın özü bakımından çok gerekli ve önemli bulduğumuz bu kurumun, Türk hukuku bakımından da incelenmesi ve ayrıca uzun yıllar uyguladığımız ama bir süredir unuttuğumuz gıyapta yargılama kurumunun da hatırlatılması gerektiği kanaatindeyiz.

\section{AMERIKAN HUKUK YARGILAMASINDAKİ DURUM}

\section{A. Amerikan Hukuk Yargılamasında Davanın Açılması ve Genel Olarak Dilekçeler Aşaması}

Türk hukukunun aksine, Amerikan hukuk yargılaması tek bir kurallar bütününden oluşmamaktadır. Amerika Birleşik Devletleri'nde elli eyalet ve başkenti içinde barındıran District of Columbia'nın yanı sıra, federal yargılama usullerini düzenleyen sistemin de dâhil olduğu çok sayıda hukuk düzeni bulunmaktadır. 1938 y1lında yürürlüğe giren Federal Usul Kanunu (FRCP), bugün eyaletlerin büyük bir kısmı tarafindan, bazı değişikliklerle birlikte kendi iç hukuklarına uyarlanmış durumdadır ${ }^{1}$. Federal mahkemelerde FRCP uygulanırken, eyalet mahkemelerinde eyaletlerin kendi usul kuralları uygulanmaktadır. Çalışmamızın kapsamının belirlenmesi bakımından, federal usul kuralları esas alınacaktır. Zaten eyaletlerin pek çoğu da aynı usulleri benimsediği için, yaptığımız açıklamaların büyük bir kısmı, eyalet hukuklarının çoğu bakımından da açıklayıcı olacaktır.

Amerikan hukuk yargısında, davanın açılması ve dilekçeler aşaması (pleading), eski common law uygulamalarından çok farklı bir şekle bürünmüş ve oldukça basitleştirilmiştir ${ }^{2}$. Federal Usul Kanunu'nun, 2'nci maddesinde tek bir dava türü olduğu belirlenmiş (medeni dava - civil action) ve 3'üncü maddede de medeni davanın mahkemeye sunulacak (yazılı) bir dava dilekçesi ile açılacağı düzenlenmiştir. Davacı dava dilekçesinin yanı sıra, davalıya yönelik olarak hazırladığı davetiyeyi (celbi) de mahkeme yazı işlerine (clerk) sunar (FRCP m. 4/b). Yazı işleri bu davetiyeyi kontrol ettikten sonra, davetiyeyi imzalayıp mühürler ve tebligatın gerçekleştirilmesi hakkında gerekli işlemleri yapması için davacıya geri verir; her bir davalı için ayrı ayrı davetiye düzenlenmek zorundadır. Davetiye, dava dilekçesi ile birlikte davalıya tebliğ edilmelidir (FRCP m. 4/c/1). Davetiyede bulunması gereken

1 Charles F. Abernathy, Law in the United States, International Law Institute, 1995, s. 659.

2 Fleming James/ Geoffrey C. Hazard/ John Leubsdorf, Civil Procedure, 5th Edition, Foundation, 2001, s. 187- 188. 
hususlar Kanunda sayılmıştır; davalının, dava dilekçesini cevapsız bırakması halinde gıyapta hükümle karşılaşabileceği ihtarı da bu hususlardan birisidir (FRCP m. 4/a/1/E). Amerikan hukukunda, Türk hukukunun aksine, dava dilekçesinin tebliği kural olarak resmi organlarca yapılmamaktadır³. Dava dilekçesinin tebliği, 18 yaşından büyük ve davada taraf olmayan herhangi birisi tarafından gerçekleştirilebilir (FRCP m. 4/c/2). Ancak, davacının talebi üzerine, mahkeme, tebligatın resmi bir görevli tarafından yapılmasına da karar verebilir (FRCP m. 4/c/3). Tebligatın masraflı olduğu varsayımından hareketle, yine Türk hukukundan farklı olarak, tebligattan feragat yükü de Kanunda düzenlenmiştir. Kanuna göre ABD'de bulunan bir davalı, davacı tarafindan Kanuna uygun şekilde hakkında açılan davadan haberdar edilmesi halinde, tebligattan feragat etme yükünü taşımaktadır (FRCP m. 4/d). Mahkeme, tebligattan haklı bir sebep olmaksızın feragat etmeyen davaliya, tebligatla ilgili masrafları yüklemek zorundadır. Tebligattan feragat aslında davalı bakımından da olumlu bir sonuç doğurmaktadır. Zira davaya cevap verme süresi, bu ihtimalde daha uzundur. Tebligattan feragat ettiğini zamanında bildiren davalı, davaya 60 günden önce ( $\mathrm{ABD}$ dışındaysa 90 gün) cevap vermek zorunda olmaz. Normalde bu süre 21 gündür (FRCP m. 12/a/1/i).

Yargılamanın basitleştirilmesi için, Federal Usul Kanunu'nda, dilekçeler aşamasında teati edilebilecek olan dilekçeler de sınırlı şekilde düzenlenmiştir. Buna göre taraflar kural olarak sadece dava ve cevap dilekçelerini teati edebilirler; yine kural olarak replik veya düplik dilekçesine izin verilmez ${ }^{4}$. Davalının karşı talepte bulunması veya üçüncü bir kişinin davaya dahil olması gibi özel durumlarda ise diğer bazı dilekçelere izin verilmiştir (FRCP m. 7/a). Ancak burada kastettiğimiz, dilekçeler aşamasında teati edilen davanın esasına ilişkin dilekçelerdir (pleading). Yoksa mahkemeden bazı özel talepleri içeren talep dilekçeleri (motion) bu kuraldan ayrıktır.

\section{B. Davalının Dava Dilekçesine Karşı Sahip Olduğu Araçlar}

Davaya cevap, kural olarak bir cevap dilekçesi ile olur5. Kanunun 8'inci maddesinde, dava dilekçesinin yanı sıra, cevap dilekçesinin nasıl yazılması gerektiği; diğer bir ifadeyle davaya nasıl cevap verilebileceği de düzenlenmiştir. Buna göre davalı, her bir vakıa hakkındaki savunmalarını

3 Dava dilekçesinden sonraki tebligatlar ise mahkeme kontrolünde yapılır (m. 4.1).

4 Mary Kay Kane, Civil Procedure in a Nutshell, West, 1996, s. 95.

5 Geoffrey C. Hazard/ Michelle Taruffo, American Civil Procedure, Yale University Press, 1993, s. 106. 
belirtmeli ve davacinın her bir iddiasını kabul (ikrar) veya reddetmelidir (inkâr). İnkârın görünümleri de yine aynı maddede düzenlenmiştir. Buna göre inkâr mutlaka iddianın özüne cevap verir nitelikte olmalıdır. Davalı davacının bütün iddialarını birden reddedebilir, ancak bunu kötüniyetle yapmamış olmalıdır ${ }^{6}$. Davalı, davacının iddialarının bir kısmını kabul edip diğerlerini reddedebileceği gibi, iddiaların bir kısmını açıkça inkâr da edebilir. Böyle bir durumda, açıkça inkâr edilmeyen iddialar kabul edilmiş sayılır. Davalı, yine kötüniyetli olmamak şartıyla, iddia hakkında yeterli bilgiye sahip olmadığı savunmasında da bulunabilir; bu da inkâr sonucunu doğurur. Davalı, yine Kanuna göre, cevap dilekçesinde maddi hukuktan doğan zamanaşımı, irade sakatlığı, ödeme vb. gibi tüm savunmalarını (affirmative defenses) birlikte ileri sürmelidir. HMK m. 29'da bulunan (tarafların ve vekillerinin) dürüst davranma ve doğruyu söyleme yükümlülüğ̈̈ ilkesi, Amerikan hukukunda da çok büyük önem taşımaktadır. Federal Usul Kanunu'nun 11. maddesinde, taraflarca sunulacak davaya ilişkin tüm dilekçe ve diğer yazıların imzalanması gereği ve bu imzanın, dilekçede bulunan tüm beyanatın doğru olduğu yönünde mahkemeye yönelik bir taahhüt içerdiği düzenlenmiştir. $\mathrm{Bu}$ beyanların doğruluğa aykırılığının tespiti halinde, diğer tarafın talebi üzerine mahkeme, mahkemeye veya karşı tarafa para cezası ödenmesi veya yargılama giderlerinin yükletilmesi gibi, duruma uygun olacak şekilde cezalar verebilir".

Yine Türk hukukundan farklı olarak Amerikan hukuk yargılamasında, cevap dilekçesi verilmeden önce mahkemeye bir talep dilekçesi (motion) sunulabilir. Bu talep dilekçesi, mahkemenin görevsiz veya yetkisiz olması, tebligatın usulsüz yapılmış olması veya mecburi dava arkadaşlığına uyuşmamış olması gibi hallerdir (FRCP m. 12/b). Böyle bir talepte bulunulmuş olmas1 halinde mahkeme bunları öncelikli olarak inceleyip karara bağlar. Davalının bu talebinde haksız çıkmış olması veya eksikliğin davacı tarafından giderilmiş olması halinde, davalının cevap dilekçesini sunması gerekir ${ }^{10}$.

6 Karş. HMK m. 329.

7 Larry L. Teply/ Ralph U. Whitten, Civil Procedure, Fourth Edition, Foundation Press, 2009, s. 577

8 Murice Rosenberg/ Hans Smit/ Rochelle Cooper Dreyfuss, Elements of Civil Procedure, Fifth Edition, Foundation Press, 1990, s. 563.

9 Peggy Kerley/ Joanne Banker Hames/ Paul A. Sukys, Civil Litigation, 6th Edition, Delmar, 2012, s. 194.

10 Kerley/Banker Hames/Sukys, s. 194. 
Amerikan Hukukunda, bazı şartların gerçekleşmiş olması halinde (örneğin aynı hukuki işlemden doğması) davalının karşı taleplerini (karşı dava) aynı davada bir savunma olarak ileri sürmesi, Türk hukukunun aksine, zorunludur (FRCP m. 13/a). Bu şartların bulunmadığ1 hallerde ise karş1 dava açılıp açılmaması davalının takdirindedir (FRCP m. 13/b). Yine bizim hukukumuzdan farklı olarak, bir tarafi oluşturan arkadaşların kendi aralarında bir talep ileri sürmeleri de mümkündür (yan dava ${ }^{11}$ ); tüm bu ihtimallerde karmaşık dava usulleri (complex litigation ${ }^{12}$ ) söz konusu olmaktadır.

Duruşmalar aşamasına geçilmeden önce, cevap dilekçesi, bir kereye mahsus olmak üzere ilgili tarafça değiştirilebilir (FRCP m. 15) ${ }^{13}$. Bu hak, davalıya sadece bir kez verilmiş olan bir haktır ve kural olarak, dilekçenin karşı tarafa tebliğinden itibaren 21 gün içinde kullanılmalıdır. Bunun dışındaki değişiklikler (dilekçenin ıslahı), karşı tarafın yazılı rızasına bağlıdır. Ancak, hukukumuzdan farklı olarak, karşı tarafin rızası olmasa dahi, mahkeme adaletin gerektirmesi halinde tarafin, dava veya cevap dilekçesini (ya da davanın esası hakkındaki diğer dilekçeleri) değiştirmesine izin verebilir. Duruşmalara geçilmiş olması halinde ise ${ }^{14}$, dilekçelerin 1slahı nispeten daha kolaydır. Örneğin duruşma sırasında, daha önce dilekçelerde ileri sürülmemiş olan bir sorun duruşma sırasında gündeme getirilir ve karşı taraf buna hemen itiraz etmezse, bu sorun dilekçelerde ileri sürülmüş gibi mahkemede incelenir (FRCP m. 15/b/2).

11 İbrahim Ermenek, Medeni Usul Hukukunda Davaların Birleştirilmesi ve Ayrılması, Yetkin, 2014, s. 64 vd.

12 Richard H. Field/ Benjamin Kaplan/ Kevin M. Clermont, Civil Procedure, Foundation Press, 1997, s. 1246.

13 Aynı hak davacı bakımından dava dilekçesi için de vardır.

14 Amerikan hukukunda, bizdekinin aksine kesintisiz duruşma sistemi uygulanmaktadır. Yani duruşmalar hukukumuzdaki gibi geniş bir zaman aralığına yayılmamakta, duruşmalar öncesi aşamada deliller vs. toplandıktan sonra başlayıp, hemen bitmektedir. Ayıca ABD'de, Common Law kökenli diğer hukuk sistemlerinde de olduğu gibi duruşmalar aşamasına geçilmeden önceki sulh oranı çok yüksektir; farklı istatistikler göz önüne alındığında bu rakamın yüzde doksandan aşağı olmadığı görülmektedir Deborah R. Hensler, "USA National Report", in C. Hodges, S. Vogenauer, M. Tulibacka (eds.), The Costs and Funding of Civil Litigation, Hart/Beck, 2010, s. 535; James Maxeiner, "The American 'Rule': Assuring the Lion His Share", in M. Reimann (ed.) Cost and Fee Allocation in Civil Procedure, Springer, 2012, s. 295. 


\section{Genel Olarak Giyapta Hüküm (Default Judgment), Gıyapta Hükmün Şartları ve Türleri}

Amerikan hukukunda, davalının davacının iddialarını inkâretmesi zorunlu olduğu için, açıkça inkâr edilmemiş olan vakıalar çekişmeli olmaktan çıkar ${ }^{15}$. $\mathrm{Bu}$ da Türk hukuku ile Amerikan hukuku arasındaki, konumuzla bağlantılı en önemli farklardan birisini ortaya koymaktadır: Amerikan hukukunda daval1, davaya mutlaka cevap vermek zorundadır ${ }^{16}$. Davalının davaya cevap vermemesi halinde, davacı hemen harekete geçerek gıyapta hüküm kurumunu işletmeye başlayabilir. Zira aşağıda Türk hukuku kısmında daha ayrıntılı şekilde anlatacağımız üzere, Türk hukukunda konumuz hakkındaki en temel düzenleme olan HMK m. 128 hükmünün ("Süresi içinde cevap dilekçesi vermemiş olan davall, davacının dava dilekçesinde ileri sürdüğ̈̈ vakıaların tamamını inkâr etmiş sayılır”), karşılığı, Amerikan hukukunda bulunmamaktadır. Amerikan hukuku, diğer bütün Common Law kaynaklı sistemler gibi gerçek anlamda çekişmeli (adversarial) sistemi benimsediği için, aleyhine dava açılan tarafa bir savunma ve inkâr yükü yüklemiştir ${ }^{17}$.

Default kelimesinin pek çok anlamı bulunmakla birlikte, konumuz bakımından anlamı, yokluk veya eksikliktir; yani taraflardan birisinin yargılama sürecine katılmamasını ifade etmektedir. Bizim hukukumuzda eskiden bulunan gıyapta yargılama kurumu ile paralellik kurulması açısından, default ve default judgment kavramlarının karşılığı olarak giyap ve gıyapta hüküm kavramlarını kullanmayı uygun bulduk. Gıyap ve gıyapta hüküm kurumları, tarihsel gelişim ve kökenleri itibariyle aslında davalı bakımından söz konusu olan kurumlardır. Bir davalının davaya cevap vermemesi veya dava ile ilgilenmemesi, davayı görmezden gelmesi hallerinde, davacının talebi üzerine davalı hakkında gıyap kararı verilebilir ve bu kararın sonucu olarak giyapta hüküm kurulabilir ${ }^{18}$. Ancak kurumun bu tarihsel kimliğine ek olarak, aşağıda anlatacağımız istisnai bazı durumlarda davacı bakımından da giyapta hüküm kurumunun işletilmesi mümkün olmaktadır. Aslında davacının yokluğu (gaipliği) bakımımdan Federal Usul Kanunu'nda ayrı bir hukuki çare öngörülmüştür. Kanunun m. 41/b hükmü, davalıya, mahkemeye

\footnotetext{
15 Tepply/Whitten, s. 577.

16 Arthur J. Park, "Fixing Faults in the Current Default Judgment Framework.", Fall 2011, 34(1), Campbell Law Review, s. 158.

17 Teply/Whitten, s. 888.

18 Michael A. Pohl, "Judgments by Default in Texas", 1983, 37(2), SMU Law Review, s. 422.
} 
başvurarak, davayı takipsiz bırakan veya mahkemece istenilen hususları yerine getirmeyen davacı hakkında, davanın (esastan) reddini talep edebilme hakkını tanımaktadır. Davanın reddedilip edilmeyeceği veya sonuçları hakkında, mahkeme takdir yetkisine sahiptir ${ }^{19}$.

Giyapta hüküm kurumu, Kanunun 55. maddesinde düzenlenmiş ve açıkça davalı kavramı kullanılmamıştır. Hükme göre gıyap, cevap vermesi gereken bir tarafin bu cevabı sunmaması veya başka bir şekilde savunma yükünü yerine getirmemesi halinde söz konusu olur. Dolayısıyla karşı dava gibi bir durumda, davacının da gaip durumuna düşmesi mümkündür. Cevap verilmemesi veya cevap verilmesinden sonra duruşmalara katılmama durumlarının yanı sıra, bir tarafın duruşma öncesi aşamada, özellikle delil toplanması (discovery veya disclosure) faaliyeti sırasinda mahkemece verilen talimatları yerine getirmemiş olması hallerinde de, Kanunun m. 37/b hükmüne göre, gıyapta hüküm verilebilmesi mümkündür. Buna göre, dört halde gıyap söz konusu olabilir:

(1) Davalının (veya karşı talep halinde davacının) davaya cevap vermemiş olması;

(2) Davalının (veya karşı talep halinde davacının) cevap verdikten sonra duruşmalara katılmamış olması;

(3) Taraflardan birisinin, duruşmalar öncesi aşamada mahkemenin talimatlarına aykırı davranmış olması;

(4) Kanuna göre saklanması gereken elektronik verilerin silinme yoluyla yok edilmiş ve bunu silen tarafin kötüniyetli olduğunun anlaşılmış olması.

$\mathrm{Bu}$ sebeplerden ilk ikisi Kanunun 55'inci maddesinde, diğer ikisi ise 37'inci maddesinde düzenlenmiştir. Son iki sebep, aslında, gerçek bir gıyap halinden ziyade bir yaptırım olarak öngörülmüştür ${ }^{20}$.

Kanunda düzenlenmiş olan son iki sebebin mahkemece uygulanabilecek bir yaptırım olması bir tarafa bırakılacak olursa ${ }^{21}$, gerçek (klasik) anlamda gıyap halinin şartları Kanunun 55'inci maddesinde düzenlenmiştir. Buna göre, yukarıda da ifade ettiğimiz üzere, cevap vermesi gereken bir tarafın cevap vermemesi veya başka bir şekilde savunma yükünü yerine getirmemiş olması

19 Kay Kane, s. 169.

20 Kay Kane, s. 164.

21 James/Hazard/Leubsdorf, s. 332. 
halinde aslında gıyap durumu oluşmuş demektir. Ancak elbette bu duruma bir resmiyet kazandırılması gerekmektedir. Buna göre davac1 ${ }^{22}$, davadaki talep sonucu likit ise mahkeme yazı işlerine, değil ise doğrudan mahkemeye başvurur. Her halükârda önce yazı işleri tarafından gıyap kararı verilir. Gıyap kararı bir hüküm değildir, sadece gıyap durumunu ortaya koyar ${ }^{23}$. Birinci ihtimalde, yani talep sonucunun likit olması halinde, prosedür çok daha basit şekilde düzenlenmiştir. Gıyap kararı için davacı yazı işlerine başvurur ve ayrıca talep sonucunda ifade edilen tutarda alacaklı olduğunu içeren bir yazılı yemin beyanını (affidavit) talebine ekler. Böyle bir durumda yazı işleri, Kanunda aranan şartlar varsa, davalının ergin veya mümeyyiz olmayan bir kimse olması hali müstesna olmak üzere, talep edilen miktarı ve yargılama giderlerini ihtiva eden hükmü yazar. Yani bu ihtimalde hüküm mahkemece değil, doğrudan yazı işlerince, davacının talebi ve yeminli beyanı uyarınca yazılır.

Bir üst paragrafta anlattığımız özel durum dışındaki diğer bütün ihtimallerde ise mahkemeye başvurulması şarttır. İncelemenin mahkemece yapılacağı durumlarda, yeterli şekilde temsil edilmiş olması halinde, ergin veya mümeyyiz olmayan davalı hakkında da bu karar verilebilir. Davalı daha önce şahsen ya da vekili aracılığıla yargılamaya iştirak ettiyse, keyfiyet mahkemece davalıya tebliğ edilmelidir; aksi halde ise hakkında gıyap kararı istenilen davalıya bir bildirim yapılmaz. Mahkeme bir duruşma yapar ${ }^{24}$; hakkında gıyapta hüküm istenen tarafın Anayasa'dan doğan jürili yargılama hakkı da bakidir. Mahkemenin yapacağı incelemede, alacağın tutarını veya tazminatın miktarını hesaplaması ve iddianın doğruluğunu davacının sunmuş olduğu deliller aracılığıyla değerlendirmesi gerekir ${ }^{25}$. Bu ihtimalde davacının karşı tarafın kusurunu vs. ispat etmesi gerekmez; ayrıca mahkeme davacının talep sonucu ile bağlıdır, daha üstünde bir rakama hükmedemez ${ }^{26}$.Yani görüldüğü üzere, birinci ihtimalde gıyapta hüküm, şartların objektif olarak

\footnotetext{
22 Yukarıda da ifade ettiğimiz üzere, her iki taraf hakkında da gıyapta hüküm verilebilmesi mümkün olabilmekle birlikte, anlatım kolaylığı açısından bu kısımda davacı (talepte bulunan) ve davalı (gaip taraf) kavramları kullanılmıştır.

23 Park, s. 161.

24 Peter H. Bresnan/ James P. Cornelio, "Relief from Default Judgments Under Rule 60(b)--A Study of Federal Case Law”, 1981, 49(6), Fordham Law Review, s. 961.

25 Julia F. Pendrey, "Dealing with Default Judgements”, 2003, 35(1), St. Mary's Law Journal, s. 7-8.

26 Kay Kane, s. 165.
} 
bulunması halinde yazı işleri tarafından otomatik olarak verilirken ${ }^{27}$; ikinci ihtimalde mahkemenin bir takdir yetkisi bulunmaktadır ${ }^{28}$.

\section{Gıyapta Hükmün Sonuçları ve Ortadan Kaldırılması}

Gıyapta hüküm de, olağan hükümler gibi, gerçek anlamda davayı esastan çözen bir hükmü ifade eder. Gaip olan taraf, davasını savunmamış olması sebebiyle, aleyhe bir hükümle karşılaşmaktadır. Bu anlamda, elde edilen hükmün icra kabiliyeti bakımından olağan bir hükümle (kural olarak) bir fark1 bulunmamaktadır ${ }^{29}$. Bununla birlikte uygulamada, maddi anlamda kesin hüküm etkisi ve diğer hukuk sistemlerinde tenfiz bağlamında gıyapta hükümlere, gerçek anlamda bir yargılama yapılmamış olduğu için, genellikle tereddütle yaklaşıldığ görülmektedir ${ }^{30}$. Giyapta hüküm verilmesinin bir diğer sonucu da yukarıda bahsettiğimiz üzere, davalı tarafça karşı dava açılmasının zorunlu olduğu hallerde, davalının bu talepleri ayrı bir davada ileri sürmesi mümkün olmadığı için hak kaybına uğrayabilmesidir ${ }^{31}$.

Giyapta hükmün, itiraz üzerine mahkemece iptal edilebilmesi mümkündür. Öncelikle mahkeme, yazı işleri tarafından verilmiş olan gıyap kararını, geçerli bir sebebe dayanarak iptal edebilir. Örneğin dava dilekçesi usulsüz tebliğ edilmişse veya aslında bir cevap verilmiş olmasına rağmen cevap verilmemiş gibi gıyap kararı verilmişse, mahkeme bu kararı iptal eder. Mahkemenin giyapta hükmü iptal etmesi ise daha sinırlı bir yoldur. Kanun, bu çerçevede m. 60/b hükmüne atıf yapmıştır. Kanunun m. 60/b hükmü,

27 Eric B. Levasseur, "Default Judgments: Strategies for Making Them Stick and for Making Them Go Away", Fall 2015, 42(1), Litigation, s. 48.

28 Teply/Whitten, s. 890, Benjamin Kaplan/ Kevin M. Clermont, "Chapter 6: Ordinary Proceedings in First Instance" in M. Cappalletti (ed.), International Encyclopedia of Comparative Law, Volume XVI: Civil Procedure, Mohr Siebeck, 2014, s. 25; John T. Holleman, "Revised Rule 55 Revisited", Spring 1999, 21(3), University of Arkansas at Little Rock Law Review, s. 444.

29 Jesse N. Panoff, "Debtors, Creditors, Default Judgments, \& Discretion: Why Rule 62(b) (4) Will Become One of the Most Important Federal Rules of Civil Procedure", 2010, Vol. 44(1), Creighton Law Review, s. 228.

30 Bernice B. Donald/ Kenneth J. Cooper, "Collateral Estoppel In Section 523(C) Dischargeability Proceedings: When Is A Default Judgment Actually Litigated?", 1996, (12), Bankruptcy Developments Journal, s. 332; Panoff, s. 235. Alman hukukunda verilen giyapta hükümlerin tanınma ve tenfizi ile ilgili olarak bkz. Acun Papakçı, "Alman Mahkemelerince Verilen Gıyabi Kararların Yargılama ve Uluslararası Tebligat Kuralları Açısından Türk Hukukuna Uygunluğu”, 2016, 22(1), Marmara Üniversitesi Hukuk Araştırmaları Dergisi, s. 457-487.

31 Todd David Peterson, "The Misguided Law of Compulsory Counterclaims in Default Cases", 2008, Vol. 50, no. 4, Arizona Law Review, s. 1108. 
mahkemeye, Kanunda yazılı şartların gerçekleşmiş olması halinde hükmün ortadan kaldırılabilmesi yetkisi tanımaktadır. Bu durum ilk bakışta bizim hukukumuza çok yabancı gibi gözükse de aslında HMK'daki yargılamanın iadesi kurumuna benzetilebilir. Nitekim hukukumuzda yargılamanın iadesi de nihai kararı veren mahkemeden istenir (HMK m. 378). Ayrica Amerikan hukukunda, Orta Avrupa hukuklarında olduğu şekilde bir şekli anlamda kesinleşme kurumunun bulunmadığı da gözden kaçırılmamalıdır. Federal Usul Kanunu'nun m. 60/b hükmüne göre bir hüküm veya başka bir mahkeme kararı, (1) hata, ihmalkârlık vs. içeriyorsa, (2) yargılama sırasında bulunamamış olan bir delil sonradan ortaya çıkarsa, (3) karşı tarafça hile vs. yapılmışsa, (4) hüküm geçersizse, (5) hükmün gereği itfa edilmişse, hüküm ortadan kaldırılmış başka bir hükme dayanarak verilmişse veya (6) kabul edilebilecek başka bir haklı sebep varsa, bizzat kararı veren mahkemece iptal edilebilir (kaldırılabilir).

Giyapta hükmün iptalini isteyen taraf, talebini makul bir süre içinde mahkemeye iletmelidir. Kanunda sayılan üç sebep bakımından ayrıca bir yıllık azami bir süre de bulunmaktadır. Dolayısıyla mahkemenin, iptal talebinin niteliğine göre süreyi göz önünde bulundurması gerekmektedir. Mahkeme, hakkında gıyapta hüküm verilen tarafın ileri sürdügü sebeplere göre iptal incelemesini yapar. Mahkemenin iptal incelemesi sırasında takdir yetkisi bulunmaktadır; mahkemeler bu incelemede genellikle başvuran tarafin, yeterli savunmayı yaptığın $1^{32}$ ortaya koymasını aramaktadırlar ${ }^{33}$. Tebligatın usulsüz şekilde yapılmış olması da geçerli bir sebep olabilir ${ }^{34}$. Mahkeme ayrıca, resmi bir iptal talebi olmaksızın, lehine hüküm verilen tarafın talebi veya açık rızası ile de giyapta hükmü iptal edebilir ${ }^{35}$.

\section{TÜRK HUKUK YARGILAMASINDAKİ DURUM}

\section{A. (Mülga) Giyapta Yargilama Usulï}

Mülga 1086 sayılı Hukuk Usulü Muhakemeleri Kanunu'nun 1927 yılında kabulünden, 1985 yılında kabul edilen 3156 sayılı 1086 Sayılı Hukuk Usulü

\footnotetext{
32 Hükmün geçersizliği ihtimali hariç olmak üzere (John J. Watkins, "Revised Rule 55, Five Years Later", 1996-1997, 49(1), Arkansas Law Review, s. 60).

33 Teply/Whitten, s. 890-891; Holleman, s. 449.

34 Erin Louise Palmer, "Service by Certified Mail Insufficient to Preserve Default Judgment", Summer 2015, Vol. 40(4), Litigation News, s. 18; Susan Jane Miller, "Misnomers: Default Judgments and Strict Compliance with Service of Process Rules", Summer 1994, Vol. 46(3), Baylor Law Review, s. 641.

35 Kerley/Banker Hames/Sukys, s. 196.
} 
Muhakemeleri Kanununda Değişiklik Yapılmasına Dair Kanun ile tamamen yürürlükten kaldırılıncaya kadar neredeyse altmış yıl boyunca uygulanan gıyapta yargılama kurumu, büyük ölçüde, mehaz kanun olan İsviçre Nöşatel Kantonu Medeni Usul Kanunu'ndan alınmışt ${ }^{36}$. Zaten en başta çok iyi formüle edilmemiş olan hükümler sebebiyle 1934 y1lında kabul edilen 2606 sayılı Kanunla başlayarak birkaç kez değişikliğe uğrayan kurum, daha da karmaşık bir hal almış ve bu husus öğretide çok kez eleştirilmiştir ${ }^{37}$. Bu karmaşıklık uygulamada da kendisini göstermiş ve çok sayıda birbiriyle çelişen Yargıtay içtihatlarının verilmesine de neden olmuştur.

Gıyap veya öğretide zaman zaman kullanılan diğer ifade ile yokluk ${ }^{38}$, en geniş anlamda, davadaki taraflardan birisinin yargılamaya katılmamasını ifade etmektedir. Mevcut HMK uygulamasında da "tarafin yokluğu" ifadesine çeşitli hükümlerde yer verildiği görülmektedir (örn. HMK m. 79, 96, 139, 150). Tarafın yokluğu, yani gaipliği halinde uygulanacak usul ise iki sistem arasındaki farklılığı ortaya koymaktadır. Mevcut HMK uygulamasında, taraf yokluğu halinde, $79,80,82$ ve 83 'üncü maddelerde yer alan "tarafın yokluğu halinde uygulanacak hükümlere göre" ifadesi dışında aslında genel bir uygulama şekli bulunmamaktadır. Belirli bazı hükümler çerçevesinde tarafların yokluğunun ayrı şekilde sonuçlarının düzenlendiği görülmektedir (örn. HMK m. 139, 150). 1985 yılına kadar uygulaması süren giyapta yargılama usulü ise, söz konusu yokluğa bağlanmış olan genel bir usulü düzenlemekteydi. Bu çerçevede tarafın gaipliğine, duruşmalara kabul edilmemeden başlayarak, hükmün yokluğunda verilmesine kadar çok sayıda sonuç bağlanmıştı.

Gıyapta yargılama hükümleri zaman içerisinde değişmekle birlikte genel yapısının korunduğu görünmektedir. Bu çerçevede, makalemizin konusu ile doğrudan bağlantılı olarak kurumla ilgili en önemli değişikliğin, 1934 y1lında, 2606 sayılı Kanunla 398'inci maddede yapıldığ 1 söylenebilir. Maddenin ilk hali "Ikki taraftan biri tayin olunan günde tahkikat hâkimi nezdinde

361086 sayılı Hukuk Usulü Muhakemeleri Kanunu'nun kabulü öncesinde de hukukumuzda benzer hükümler bulunuyordu. Bunlar hakkında ayrıntılı bilgi için bkz. Mehmet Doğan, Hukuk Muhakemeleri Usulünde Gıyapta Yargılama ve Dosyanın İşlemden Kaldırılması, Yargıcıŏlu Matbaas1, 1979, s. 18-20.

37 Necip Bilge/ Ergun Önen, Medeni Yargılama Hukuku Dersleri, Üçüncü Baskı, Sevinç Matbaası, 1978, s. 616, Sabri Şakir Ansay, Hukuk Yargılama Usulleri, Yedinci Bask1, Güzel Sanatlar Matbaas1, 1960, s. 327.

38 Ergun Önen, Medeni Yargılama Hukuku, Sevinç Matbaas1, 1979, s. 190; Ömer Ulukap1, “Medeni Usul Hukukunda Davada Bir Tarafin Duruşmaya Gelmemesi”, 1988, (1), SÜHFD, s. 171 . 
veya mahkemede hazır bulunmadĭ̆ veya cevabnamesini göndermediği veyahut bulunubda cevabdan imtina eylediği takdirde giyab karart verilir" şeklinde iken, 2606 sayılı Kanunla madde metni "Iki taraftan biri tahkikat veya muhakeme için tayin olunan günde gelmediği veya gelib de cevabdan kaçındiğı takdirde hakkında gıyab kararı verilir" ş̧eklinde değiştirilmiştir. Görüleceği üzere bu değişiklik ile "cevapname verilmemiş" olması hali sadece yedi yıllık bir uygulama sonrasında, giyapta yargılama sebebi olmaktan çıkarılmıştır. 2606 sayılı Kanunun Hükümet gerekçesinde bu konuda herhangi bir tartışmaya yer verilmemiş; genel gerekçe olarak "Kanunun, maksadı ifade edecek şekilde kaleme alınmamış ve bu sebeple tatbikatta muhtelif içtihatlara yol açmış olması" sebebinin ifade edilmesiyle yetinilmiştir" "Teklifin Adalet Bakanlığından geldiği" ve "cevapname göndermeyenler hakkinda 198 ve 214. madde hükümlerinin bulunduğunun sebep olarak gösterildiği" ifadeleri de yine gerekçede yer almıştır. Her ne kadar Hükümet gerekçesinde işin teorik temellerine değinilmemiş olsa da öğretide bu tartışmanın yapıldı̆̆ 1 görülmektedir. Buna göre bir görüş cevapname vermeyen taraf bakımından bu hükmün doğru bir uygulama olduğunu ifade ederken, diğer bir görüş ise maddedeki cevapname kelimesinin bir hata eseri konduğunu ve cevapname verilmemesinin sonucunun 198'inci madde hükmünde zaten düzenlendiğini savunmuştur $^{40}$. Aslında ilginç olan durum, mevcut HMK'da karşıllığ bulunmayan HUMK m. 198 hükmünün bizzat kendisidir. Bu hüküm, "Yukarlki maddede gösterilen sebeplere mebni, tayin olunan müddette cevap lâyihasinı vermemis ve yeni mühlet de istememiş olan taraf muhakeme celsesinde de esasa girişmezden evvel bu baptaki mazeretini bildirerek müddetin temdidini isteyebilir. Talebi kabule şayan görülürse kendisine suret-i katiyede üç günü tecavüz etmemek üzere mühlet verilir. Ancak bu celseye ait muhakeme masrafi her halde kendisine tahmil olunur." şeklinde idi. Yani cevap dilekçesi vermemiş olan davalıya da duruşmaya çağrılarak kendisini sözlü olarak müdafaa etme imkânı verilmekteydii ${ }^{41}$. Bu çerçevede 198 'inci madde uyarınca henüz kendisi sözlü olarak savunma imkânı verilmemiş olan davalıya, sırf cevap dilekçesi vermediği için gıyapta yargılama hükümlerinin işletilmesi, yani gıyap kararı verilmesinin sıkıntıya yol açacağ açıtır $^{42}$.

\footnotetext{
92606 sayılı Kanunun Hükümet Gerekçesi: <https://www5.tbmm.gov.tr/tutanaklar/ TUTANAK/TBMM/ d04/c025/tbmm04025015ss0029.pdf>, Erişim tarihi: 12.09.2021.

$40 \mathrm{Bu}$ tartışmalar için bkz. Doğan, s. 48-49.

${ }_{41}$ Mustafa Reşit Belgesay, Hukuk Usulü Muhakemeleri Kanunu Şerhi, Teoriler, 3. Bası, Duygu Matbaas1, 1948, s. 271.

42 Doğan, s. 48.
} 
Cevapname verilmemesi ile ilgili diğer bir husus da, cevapname verilmemesinin kendi başına gıyap hali olmaktan çıkarılmasından sonra, 398'inci madde hükmünün 2606 sayılı Kanunla değişik halinin de yine bizi bu sonuca götürüp götüremeyeceğidir. Kanunda "veya gelib de cevabdan kaçındı̆̆ takdirde hakkında gıyab kararı verilir" hükmü de kanaatimizce bizi aynı sonuca götürmektedir. Yani hiç cevap dilekçesi vermemişse ve çağırıldığı duruşmaya gelmemişse nasıl gıyap kararı verilecekse, gelip de cevap vermemişse de gıyap kararı verilecektir. Dolayısıyla aslında sonuç aynı olmalıdır. Ancak zaman içerisinde, hukuki dinlenilme hakkı ve adil yargılanma hakkı gibi kavramların daha çok önem kazanması sebebiyle ve "cevap dilekçesi verilmemesinin" yaptırımı da Kanunda açıkça düzenlenmemiş olduğu için bu durumun davayı inkâr sonucunu doğurması ilkesinin hem uygulama hem de öğretide giderek yerleştiği görülmektedir ${ }^{43}$. Nitekim bu konudaki tereddüt 6100 sayılı Hukuk Muhakemeleri Kanunu'nda giderilmiş ve davalının cevap dilekçesi vermemesinin inkâr sonucu doğurduğu hususu Kanunun 128'inci madde hükmü ile açıklığa kavuşturulmuştur.

Gıyapta yargılama, yukarıda da ifade ettiğimiz üzere, iki taraftan birisinin tahkikat veya muhakeme için tayin olunan günde gelmediği veya gelip de cevaptan kaçındığı takdirde uygulama bulan bir usuldür. Medeni usul hukuku her ne kadar tasarruf ilkesine dayanıyor olsa da yargılamanın sağl1klı bir şekilde yürüyüp gerçeğe uygun karar verilebilmesi için taraflara bir katılma ödevi düştüğü de aşikârdır. Bu ödev, tarafların (ve vekillerinin) dürüst davranma ve doğruyu söyleme yükümlülüğü ilkesi ile de doğrudan bağlantılıdır. Bu çerçevede modern bir usul hukukunda tarafların birbirlerinin iddialarını cevapsız bırakmalarının veya duruşmalara katılmayarak adaletin tecellisine katkıda bulunmamalarının bir yaptırımı da olması gerekmektedir ${ }^{44}$. $\mathrm{Bu}$ zorunluluk, mülga 1086 sayılı HUMK'ta da gıyap hükümlerinin yanı sıra, tarafların her ne kadar duruşmaya zorla getirilemeseler de duruşmalara katılmamaları halinde taraflara para cezası öngörülmüş olması hallerinde görülmekteydi (HUMK m. 412). Ancak bu para cezasının hiç arttırılmamış olması sebebiyle zaman içerisinde uygulanamaz hale geldiği de kabul

43 Leyla Akyol Aslan, Medeni Usul Hukukunda Cevap Dilekçesi Verilmemesinin Sonuçları, Yetkin, 2019, s. 278; Doğan, s. 48; Yavuz Alangoya, Medeni Usul Hukukunda Vakıaların ve Delillerin Toplanmasına İlişkin İlkeler, Fakülteler Matbaası, 1979, s. 125-126; Saim Üstündağ, Medeni Yargılama Hukuku, Cilt I-II, 6. Bası, Alfa, 1997, s. 343; Ali Cem Budak/ Varol Karaaslan, Medeni Usul Hukuku, 4. Bask1, Adalet, 2020, s. 194.

44 Belgesay, s. 271; Orhan Yılmaz, “Adi ve Muameleli Gıyap Hakkında Bir İnceleme”, Aralık 1972, (12), Adalet Dergisi, s. 907. 
edilmekteydi ${ }^{45}$. Nitekim bu hüküm de 3156 sayılı Kanunla, gıyap hükümleri ile birlikte yürürlükten kaldırılmıştır. $\mathrm{Bu}$ yönde bir hüküm $\mathrm{HMK}$ 'da da bulunmamaktadır.

Gıyapta yargılama hükümleri hem davalı hem de davacı bakımından işletilebilmekteydi ${ }^{46}$. Gıyap kararı verilebilmesi için taraflardan birisinin duruşmaya gelmemesi veya duruşmada sorulan sorulara cevap vermemesi gerekiyordu. Diğer tarafin ise gelmiş olması şarttı; aksi halde şimdi olduğu gibi dosya işlemden kaldırılıyordu. Kanunda her ne kadar bir hüküm bulunmasa da öğreti ve Yargıtay'a göre hâkim resen gıyap kararı veremiyordu, gelen tarafın bu yönde bir talebi olması gerekiyordu ${ }^{47}$. HUMK'un 195'inci maddesinin 2494 sayılı Kanunla (1981) değişmeden önceki haline göre, ilk itiraz ileri süren davalının esasa cevap vermek zorunluluğu olmadığı ve ilk itirazların incelenmesinde taraf teşkiline gerek olmadığı için bunların incelendiği duruşmaya gelmeyen taraf hakkında gıyap kararı verilemiyordu ${ }^{48}$. Keza, taraflardan birisinin sadece hükmün tefhim edileceği duruşmaya gelmemesi halinde de gıyap kararı verilebilmesi mümkün değildi (m. 410).

Gıyap, uygulamada ve öğretide âdi (muamelesiz-işlemsiz) gıyap ve muameleli (işlemli) gıyap olarak ikiye ayrılmaktaydı. Kanunda aslında böyle bir ayrım bulunmamakla birlikte, 401 ve 402'nci madde hükümlerindeki farklılıklar sebebiyle bu ayrım yapılmaktaydı. Âdi giyapta (HUMK m. 401), mahkeme duruşmada hiçbir işlem yapmadan duruşmayı erteler ve gelmeyen tarafa meşruhatlı bir davetiye gönderir; tayin olunan günde duruşmaya gelmesi konusunu ona ihtar ederdi. Taraf bir sonraki duruşmaya gelirse veya cevap vermemiş olan taraf cevap verirse gıyap kararı kaldırılırdı. Aslında bunun gerçekte bir gıyap kararı olmadığı, henüz ortada bir gıyap kararının bulunmadığı, bir sonraki duruşmaya gelmemesi halinde sonucun doğacağı; dolayısıyla aslında Kanunda meselenin yanlış ifade edildiği yönünde bir görüş de mevcuttu ${ }^{49}$. 402 'nci maddede düzenlenmiş olan muameleli gıyap ise daha karmaşık bir ihtimali ifade ediyordu. Buna göre, "glyap kararı verilen celsede muayyen muamelât klsmen veya tamamen ifa olunmuş ise tebliğ

\footnotetext{
45 Doğan, s. 154.

46 Müdahil bakımından gıyap kurumu mümkün değildi (Bilge/Önen, s. 616.)

47 Bilge/Önen, s. 617; İlhan Postacıoğlu, Medeni Usul Hukuku Dersleri, Altıncı Bası, Sulhi Garan Matbaas1, 1975, s. 506-507.

48 Ünal, s. 570; Belgesay, s. 273.

49 Y1lmaz, s. 911; Aksi görüş, Doğan, s. 69.
} 
varakasında yapılan muamelât yazılıp gaibe beş gün içinde itiraz edebileceği" bildiriliyordu. Gaip bu müddet içinde muameleye devam için mahkemeye müracaatla diğer bir gün tayin ve hasma tebliğ ettirebiliyordu. Yargitay'ın zaman içerisinde verdiği farklı yöndeki içtihatları sebebiyle bu hükmün uygulanması da tartışmalı olmuştur. Kanun açıkça beş günlük sürenin yeni duruşma günü tayini için olduğunu ifade etse de uygulamada mahkemeler bir sonraki duruşma gününü de tayin ediyorlar; bu sebeple de Yargıtay bu beş günlük süreyi, yapılan işlemlere itiraz süresi olarak addediyordu; yani taraf sırf gaip duruma düşmemek için, belki de aslında herhangi bir itirazı olmadığı işlemlere itiraz etmek zorunda kalıyordu ${ }^{50}$.

Uygulamada Yargıtay'ın, özellikle 1954 yılından itibaren ${ }^{51}$ vermeye başladığı farklı içtihatları sebebiyle âdi ve muameleli gıyap arasında büyük farklar yaratıldığı görülmüş, ancak bu farklar 1976 tarihli İBK ile ortadan kaldırılmış ve bu konudaki tereddüt giderilmiştir ${ }^{52}$. Her iki gıyap türü bakımından da tarafin usulüne uygun şekilde duruşmaya çağırılmış olması ve gıyap hakkında uyarılmış olması şartt $1^{53}$. Tarafın önceden mazeret göndermiş olması ve gelen tarafin bu mazereti kabul etmemiş olması halinde, uygulamada hâkim mazeretin kabul edilip edilmeyeceğini değerlendirmekteydi; sonradan mazeret bildirilmesi halinde ise eski hale getirme hükümleri uygulanıyordu ${ }^{54}$. Örneğin tebligatın usulsüz yapılmış olması, uygulamada haklı bir sebep olarak kabul ediliyordu ${ }^{55}$.

Gıyap kararı yukarıdaki usullere göre verildikten sonra, bu kararın gelen tarafin talebi (ve masrafları yatırması) ile gaip tarafa tebliği ve gaip tarafin da kendisine yapılan uyarıya uymaması halinde gaiplik kararı kesinleşiyordu. Eğer gelen taraf beş gün içinde bu yönde bir talepte bulunmazsa gaiplik kararı kendiliğinden ortadan kalkıyor (Kanundaki eski ifade ile keenlemyekün oluyor- HUMK m. 400); gaip tarafın bir sonraki duruşmaya gelmesi ve beş

\footnotetext{
50 Bilge/Önen, s. 621; Ünal, s. 571; Doğan, s. 91. BELGESAY, “o gün yapılması gereken işlerin hepsi yapılmayıp bir kısmının tayin edilen bir sonraki duruşmaya bırakılmış olması halinde hakkında gaiplik kararı verilen tarafin itiraz etmesine gerek olmadiğını, duruşmaya gelerek itirazını bildirebileceğini” ifade etmiştir (Belgesay, s. 274).

51 Y1lmaz, s. 909.

52 Karar ve açılklama için bkz. Bilge/Önen, s. 620.

53 Doğan, s. 86.

54 Ünal, s. 570.

55 Ünal, s. 570.
} 
gün içinde yapılan işlemlere itiraz etmesi halinde ise karar kaldırılıyordu ${ }^{56}$. Buna karşılık duruşmaya gelip de cevap vermeyen ve bu sebeple hakkında gaiplik kararı verilmesine neden olan tarafa tebligat yapılmayacağ 1 Kanunda açıkça düzenlenmişti (HUMK m. 400/II). İhtiyari dava arkadaşlığında davacı veya davalı tarafı oluşturan her bir kişi bakımından ayrı ayrı gaiplik kararı verilebiliyordu ${ }^{57}$. Mecburi dava arkadaşlığında ise tarafı oluşturanlardan birisi bile gelse gaiplik kararı verilmeyip yargılamaya devam edilmesi gerektiği öğreti ve uygulamada kabul görmüştür ${ }^{58}$.

Gıyap kararının kesinleşmesinin ilk sonucu, gaibin yargılamanın geri kalanına kabul edilmemesiydi. Gaibin yargılamaya kabul edilmemesi ile kastedilen, onun bir taraf sıfatı ile duruşmalara katılamamas $1^{59}$ ve yargılama ile ilgili olarak bir taraf usul işlemi yapamamasıydı; yoksa izleyici olarak duruşmalara katılmasına bir engel yoktu ${ }^{60}$. Ancak bu durumun çok önemli bazı istisnaları bulunmaktaydı: Gaip taraf duruşmaya katılmışsa ve karşı taraf da buna itiraz etmemişse; dava diğer tarafın da katılmaması sebebiyle işlemden kaldırıldıktan sonra yenilenirse ve mahkemenin nihai kararı Yargıtay'ca bozulup geri gönderilirse gaip taraf yargılamaya katılabiliyordu ${ }^{61}$. Ayrıca görevsiz veya yetkisiz mahkemece verilmiş olan gıyap kararı da dosyanın görevli ve yetkili mahkemeye aktarılmasından sonra bir sonuç doğurmuyordu ${ }^{62}$. Bunlar dişında, isticvap ve yemin için taraf, sadece bu işlemlerle sınırlı olmak kaydıyla, duruşmaya çağırılabiliyordu ${ }^{63}$. Aksine işlem yapılabilmesi için karşı tarafın rızasının gerektiği iddianın veya savunmanın değiştirilmesi yasağı ve senetle ispat mecburiyeti gibi durumlarda ise bunları gerçekleştirmek isteyen tarafın, karşı tarafa bunların sorulmasını mahkemeden isteme hakk1 bulunduğu kabul ediliyordu ${ }^{64}$.

Gaip taraf, duruşmaya katılamadığı ve/veya herhangi bir usul işlemi yapamadığı için iddia veya savunmasını değiştirip, genişletemiyordu ${ }^{65}$. Ayrıca

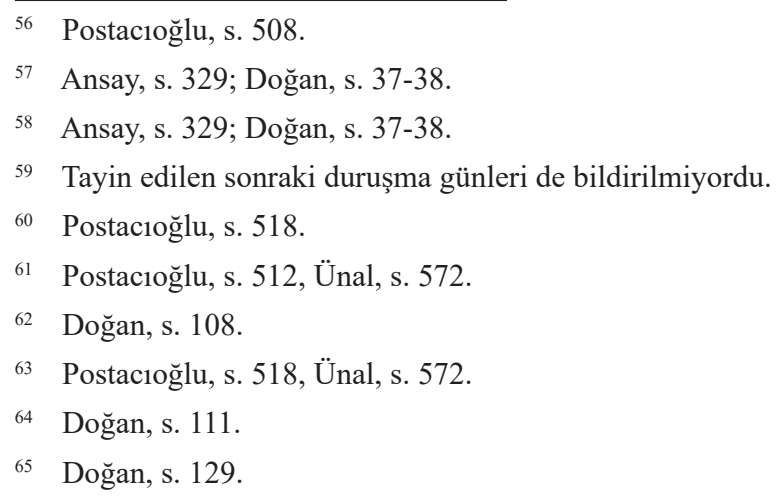


hüküm de gaip tarafin yokluğunda veriliyordu. Bu durumun en önemli sonucu, hükmün kendisinin değil, sadece hüküm sonucunun (özetin) gaip tarafa tebliğ edilmesi idi. Hüküm tebliğ edilmemesine rağmen, hükmün tebliğine bağlanan süreler hüküm sonucunun tebliği ile başliyordu (HUMK m. 407/I). Gaip taraf, ilamı ancak gıyap masraflarını ödeyerek elde edebiliyordu (HUMK m. 407/ II).

Yukarıda saydığımız sonuçlar da çok önemli olmakla birlikte, gıyap kararının hiç kuşkusuz en önemli sonucu veya etkisi, iddia ve savunma hakkının kısıtlanması bakımındandı. Öncelikle şunu söylemek gerekir ki, konu ile ilgili olarak incelediğimiz eserler ve Yargıtay içtihatlarında, bu bağlamda bir uzlaşma sağlanamamış olduğu görülmektedir. Bilhassa Kanundaki muğlak ifadeler, durumun farklı şekillerde yorumlanmasına yol açmıştır.

Mülga Kanunda bu konudaki temel düzenleme, 408'inci madde hükmünde bulunan "Muhakemeye kabul olunmayan taraf hasmının dermeyan ettiği vakıaları ikrar etmiş adolunabilir" hükmü idi. Mehaz Kanundan farklı şekilde alınan bu hüküm ${ }^{66}$, hem davacının hem de davalının gaip olmas1 ihtimalleri bakımından tartışmalara yol açmıştır. Öğretide pek ifade edilmemiş olsa da buradaki tartışmanın özünde, gaiplik kararının bir ceza olarak kabul edilip edilmemesi meselesinin yattığı söylenebilir. Nitekim BELGESAY da bu durumu, "gaip bir ceza olsun diye değil, iradesine uygun farz edildiği için vakıaları ikrar etmiş sayılabilir" şeklinde ifade etmiştir ${ }^{67}$. Tartışmayı bu özele çekmemizin temelinde, bazı yazarların sanki ilgili taraf hiç iddia veya savunmada bulunmamış gibi gaipliğin sonucunun uygulanması gerektiği, diğer bazı yazarların ise daha önceden iddia veya inkâr edilen vakıalar hakkında "ikrar" sonucunun uygulanmasının mümkün olmadığı yönünde görüş bildirmiş olmaları yatmaktadır. Örneğin ÖNEN, davacının gaip olması halinde mahkemenin davayı doğrudan (esastan) reddedebileceğini ileri sürmüş ${ }^{68}$; POSTACIOĞLU da "davalının defi olarak serdettiği vakıalar hakkında bir inkârda bulunmadan davacı hakkında giyabi usulü muhakemenin tatbiki lazım gelmişse, bu vakıaların ikrar edilmiş sayılması yerinde olur" demiştir ${ }^{69}$.

\footnotetext{
${ }^{66}$ Mehaz Kanun: "diğer tarafça ileri sürülen vakıalar hakkında izah ve beyanda bulunmadan mahkemece celselerden hariç bırakılan taraf mezkur vakıaları ikrar etmiş sayılır" (Postacioğlu, s. 517, dn. 15.)

67 Belgesay, s. 275.

68 Önen, s. 195-196; ayrıca bkz. Doğan, s. 140 ve orada zikredilen müellifler.

69 Postacioğlu, s. 517.
} 
Yargitay ise bu ihtimali (aksine kararları da olmakla birlikte) reddetmiştir ${ }^{70}$. Davalının usulüne uygun şekilde sonradan ileri sürdüğü savunmalar hakkında ise gaip davacının durumu elbette farklıdır. Bu ihtimalde HUMK 408'inci madde hükmü daha kolay uygulanabilecektir.

Davalı bakımından durum ise daha da karmaşıktır. Zira davalının gaip olma ihtimali daha yüksek olduğu için, davalı bakımından ortaya çıkabilecek ihtimaller de çeşitlidir. Davalı örneğin, yukarıda da ifade ettiğimiz üzere, hiç cevap dilekçesi vermemiş olabilir; bazı savunmaları ileri sürmüş, diğerlerini henüz ileri sürmemiş olabilir ya da davalının gaip olduğu durumda davacı taraf usulüne uygun şekilde davaya yeni vakıalar getirmiş olabilir. Bütün bu hallere, 408'inci madde hükmündeki muğlak ifadenin cevap verebilmesi mümkün olamamıștır. Bu çerçevede öğreti ve uygulamada mahkemeye verilmiş olan takdir yetkisi de tartışılmıştır. Hükümde bulunan "adolunabilir" ifadesinin, gerçek bir takdir yetkisini mi yoksa daha objektif bazı ihtimalleri mi ifade etmekte olduğu sorusunun cevaplanması gerekmektedir. BELGESAY konuyla ilgili olarak "Mahkemeye geldiği takdirde davayı ikrar etmesi oldukça kuvvetli bir olasılık içinde bulunan gaip mukir addolunmalıdır" şeklinde bir açıklamada bulunurken ${ }^{71}$, bunun gerçek bir takdir yetkisi olması halinde temyizde denetlenmesi de ayrı bir tartışma konusu olmuştur ${ }^{72}$. Bazı yazarlar ise Kanundaki ifadenin mehaz kanundaki gibi anlaşılması gerektiğini, yani sadece daha önce açıkça inkâr edilmemiş, hakkında bir cevapta veya beyanda bulunulmamış vakıaların ikrar edilmiş sayılması gerektiğini beyan etmişlerdir ${ }^{73}$. Ayrıca delil gösterilmesi bakımından da yukarıdakine benzer bir tereddüt bulunmaktaydı. Savunma yapamayan gaip tarafin kural olarak delil de gösterememesi gerekir ${ }^{74}$. Ancak daha önce gösterilmiş (ve giderleri de yatırılmış) olan delillerin incelenmesi gerektiği kabul edilmekteydi ${ }^{75}$.

Yukarıdaki tüm açıklamalar birlikte değerlendirildiğinde, Kanundaki birbiriyle çelişen ve bir bütünlük arz etmeyen, muğlak ifadeler içeren hükümler sebebiyle doğru ve tartışma doğurmayacak bir yorum yapılması,

\footnotetext{
70 Doğan, s. 140, dn 73-74.

71 Mustafa Reşit Belgesay, “Gıyap Kararları”, 1938, (102), Hukuki Bilgiler Mecmuası, s. 5669 (Doğan, s. 144'den naklen).

72 Doğan, s. 144-145.

73 Bilge/Önen, s. 627-628; Postacioğlu, s. 517.

74 Ünal, s. 572.

75 Doğan, s. 118-119; Postacioğlu, s. 516-517.
} 
bugünkü gözle bakıldığında da pek mümkün görünmemektedir. Bu sebeple özünde kanaatimizce çok mantıklı ve faydalı bir kurum olan gıyapta yargılama usulünün, HUMK'taki haliyle neredeyse altmış yıl uygulanmış olmasına rağmen, tartışmalı ve sıkıntılı uygulaması sebebiyle 1985 yılında kaldırılmasından sonra pek de özlenen bir kurum olmadığ 1 kolaylıkla söylenebilir. Çok ciddi bir kurumu ilga eden 3156 sayılı Kanunun Hükümet gerekçesinde de ne hukuki dinlenilme hakkına ne de başka bir modern ilkeye atıf yapılmış, sadece yargının hızlandırılması gereğinden bahsedilerek ve o zaman yürürlükteki basit yargılama usulü kurallarına atıf yapılarak gıyapta yargılama kurumu ve duruşmaya gelmemenin cezalandırılması hususu, Türk medeni usul hukukundan bir daha geri dönmemek üzere (en azından bu makalenin yazıldığı zamana kadar) çıkarılmışıır ${ }^{76}$.

Gıyapta yargılama kurumunun hukuki dinlenilme hakkına aykırı olduğu ifade edilmiş olmakla birlikte ${ }^{77}$, biz bu görüşe tam olarak katılamıyoruz. Hukuki dinlenilme hakkının koruduğu şey, tarafın kendisini ifade etmesine uygun imkân sağlanmasıdır ${ }^{78}$. Tarafın kendi elinde olmayan bir nedenle duruşmayı takip edememesi veya cevap dilekçesi verememesi halinde zaten, eski hale getirme kurumu (HMK m. 95-101) gibi etkin araçlar bulunmaktadır. Hâkimin (ve hatta kanun yollarında üst mahkemelerin) bu durumda dikkatli bir şekilde inceleme yapması ve hukuki dinlenilme hakkının ihlal edilmediğinden emin olmaları gerekir. Ancak hukuki dinlenilme hakkı, tarafin zorla dinlenilmesini içermez. Eğer bir taraf usul kanunlarının kendisine sağladığ 1 cevap imkânlarını kullanmıyor ve meselenin açıklığa kavuşturulmasında (uyuşmazlığın çözülmesinde) üzerine düşen ödevi yerine getirmiyorsa, bazı yaptırımlarla karşı karşıya bırakılması, elbette ki aşırıya kaçılmaması kaydıyla, kanaatimizce hukuki dinlenilme hakkını ihlal etmez. Bu noktada önemli olan, bu yaptırımların şartlarının, sınırlarının ve sonuçlarının dikkatli ve tereddüde yol açmayacak; ayrıca tarafların haklarını da gereksiz şekilde sınırlamayacak şekilde düzenlenmiş ve tarafların yeterli şekilde ihtar edilmiş olmasıdır. Nitekim yukarıda da ifade ettiğimiz üzere mülga gıyapta yargılama kurumuna benzer kurumlar, Almanya, İngiltere ve elbette ABD gibi ülkelerin hukuk sistemlerinde de halen yer almakta ve uygulanmaktadır.

\footnotetext{
763156 say1lı Kanunun Hükümet Gerekçesi: <https://www5.tbmm.gov.tr/tutanaklar/ TUTANAK/TBMM/ d17/c012/tbmm17012054ss0235.pdf>, Erişim tarihi: 09.09.2021.

77 Rüzgaresen, Medeni Usul Hukukunda Dosyanın İşlemden Kaldırılması, Yetkin, 2021, s. 79.

78 Özekes, Medeni Usul Hukukunda Hukuki Dinlenilme Hakk1, Yetkin, 2003, s. 105-106, 149; Emel Hanağası, Medeni Yargılama Hukukunda Silahların Eşitliği, Yetkin, 2016, s. 110.
} 


\section{B. 6100 Sayılı Hukuk Muhakemeleri Kanunu Sisteminde Davalının Davaya Cevap Vermemesi ve Taraflardan Birisinin Duruşmaya Katılmaması}

2011 yılında yürürlüğe giren 6100 Sayılı Hukuk Muhakemeleri Kanunu, diğer pek çok konuda olduğu gibi, davalının cevap vermemesi ve tarafların duruşmaya katılmaması halleri bakımından da bir devrimsel nitelikte bir değişiklik getirmemiştir. Yukarıda da ifade ettiğimiz üzere, mülga HUMK uygulamasinda da, Kanunda her ne kadar bu yönde bir hüküm bulunmasa da, günümüze yaklaştıkça davalının cevap vermemesi halinin davacının iddialarının inkârı anlamına geldiği yönündeki görüş baskın hale gelmiştir. 1934 yılında kabul edilen 2606 say1lı Kanunla cevapname verilmemesinin gıyap hallerinden çıkarılması da bu görüşün kabulünün önündeki engeli kaldırmıştır. Mülga HUMK uygulamasının özellikle son dönemlerinde yazılan eserler ve Yargıtay içtihatlarında bu konuda bir uzlaşma olduğu

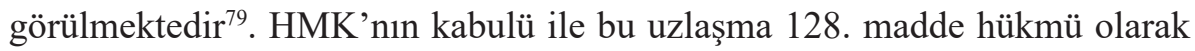
Kanuna da girmiştiir ${ }^{80}$. Buna göre, süresi içinde cevap dilekçesi vermemiş olan davalı, davacının dava dilekçesinde ileri sürdüğü vakıaların tamamını inkâr etmiş sayılır. Bu çerçevede davalı savunmalarında yalnız inkâr çerçevesinde delil gösterebilir ${ }^{81}$. Maddenin bu denli açık kabulü karşısında Türk Kanun koyucusunun, cevap dilekçesi verilmemesi hususunda gıyap müessesesinden tamamen uzaklaştı̆̆1 ve ispat yükü kurumunun daha da önem kazandiğ1 görülmektedir. Kendisine karşı açılan bir davaya cevap vermeyen ve duruşmalara dahi katılmayan, yani hiçbir savunma yapmayan bir davalı dahi, ispat yükünün davacıya düşüyor olması halinde, davayı kazanabilmektedir. Ancak hiç kuşkusuz yine bu durumun da isticvap ve yemin gibi bazı istisnaları bulunmaktadir.

Kanunun 128'inci maddesindeki bu açık düzenleme, savunma yükünün bir alt unsuru olan inkâr yükünün Türk hukukunda bulunup bulunmadığ1 sorusunu da net bir şekilde cevaplamaktadır. Kanun, davaya cevap verilmemesini bir inkâr faraziyesine bağladığı için bu yükün, pek çok hukuk

\footnotetext{
79 Akyol Aslan, s. 278.

80 Maddenin Hükümet gerekçesinde ise konunun tartış1lmadığı görülmektedir, <https://www5. tbmm.gov.tr/ tutanaklar/TUTANAK/TBMM/d23/c089/tbmm23089050ss0393.pdf> Erişim tarihi: 12.09.2021.

81 Ejder Yılmaz, Hukuk Muhakemeleri Kanunu Şerhi, 3. Cilt, 4. Baskı, Yetkin, Ankara, s. 2905.
} 
sisteminin aksine Türk hukukunda bulunmadığ kolaylıkla söylenebilecektir ${ }^{82}$. Yani Türk hukuku bakımından savunmanın yük boyutundan ziyade, hak boyutu önem kazanmaktadır. Bu çerçevede aslında Kanunun 29'uncu maddesinde düzenlenmiş olan (tarafların ve vekillerinin) dürüst davranma ve doğruyu söyleme yükümlülüğü ilkesinin sınırları da belirlenmiş olmaktadır; yani ispat yükü kuralları ve savunma hakkına dâhil olan susma hakkı, Türk Kanun koyucusu bakımından daha önemli görülmüştür. Zira susma hakkını kullanmış olan (inkâr yükünü yerine getirmeyen) davalı (kural olarak) cezalandırılmamakta, savunma hakk1 yalnızca 141'inci madde kapsamında, yani savunmanın değiştirilmesi ve genişletilmesi yasağı boyutunda sınırlandırılmaktadır. Böylece davalıya getirilmiş olan yasağın kamu düzeni ile ilgili olmadığı, tamamen tasarruf ve taraflarca getirilme ilkesi bağlamında tarafların tasarrufuna bırakılan bir alanda bulunduğu görülmektedir. Zira davacının açık rızası veya ıslah kurumları ile savunmanın genişletilebilmesi mümkün hale gelebilmektedir.

Davalının savunmasını genişletmemesi ve sadece inkâr çerçevesinde delil gösterebilmesi durumunun da yine Türk hukuk yargılaması bakımından sıkıntılı bir şekle büründügü görülmektedir. Yukarıda da ifade ettiğimiz üzere, davaya cevap vermeyen davalı yalnızca inkâr çerçevesinde delil gösterebilir. Ancak delil gösterme konusundaki temel hüküm olan 145'inci madde, bu konuda bazı tereddütler içerdiği için, uygulamada farklı içtihatlara yol açmıştır. Kanun koyucu aslında kanaatimizce çok doğru bir yaklaşım sergileyerek 145 'inci maddenin lafzını muğlak olarak kaleme almıştır. Zira hükümde "Taraflar, Kanunda belirtilen süreden sonra delil gösteremezler" ifadesi yer almakta, bu "zaman"ın ne olduğu ise hükümde yazmamaktadır. $\mathrm{Bu}$ "zaman", hiç kuşkusuz farklı ihtimallere göre mahkeme tarafindan belirlenecektir. Kural olarak davacı dava dilekçesinde (HMK m. 119), davalı ise cevap dilekçesinde (HMK m. 129) delillerini sunarlar. Ancak delil gösterme zamanı bunlarla sınırlı değildir. Taraflar vakıalarını ikinci dilekçelerle de sunmuş olabilirler; o zaman deliller de ikinci dilekçeler ile gösterilir. Taraflar iddia veya savunmalarını hukuka uygun şekilde değiştirir veya genişletirlerse, örneğin sslah yaparlarsa, yeni getirdikleri vakıaları ispat edecekleri delilleri de bu islah işlemiyle birlikte göstermelidirler ${ }^{83}$. İstisnai

82 Akyol Aslan, s. 294, 301; Levent Börü, Medeni Usul Hukukunda İddia ve Somutlaştırma Yükü, Yetkin, 2016, s.149 vd.

83 Hatta 7251 sayılı Kanunla değişmeden önce, taraflardan birisinin ön inceleme duruşmasına gelmemesi halinde diğer tarafın iddiasını veya savunmasını genişletmesi halinde de durum böyleydi. 
bir durum olan 128'inci madde hükmü çerçevesindeki savunma halinin de bu şekilde düşünülüp davalı tarafa inkâr faraziyesiyle sınırlı olacak şekilde delillerini sunması için uygun bir (kesin) süre verilmelidir ${ }^{84}$. Ancak HGK, verdiği çok sayıda kararda, bunun aksini düşünmekte ve 145 'inci maddeyi gerekçe göstererek davalının delil sunmasına izin vermemektedir ${ }^{85}$. Oysaki yukarıda da ifade ettiğimiz üzere 145'inci madde hükmünün lafzı ve ruhu kesinlikle bu denli kısıtlayıcı değildir. Kanaatimizce 145'inci maddenin bu kadar katı uygulanması 128 'inci madde hükmünün ruhuna da aykırıdır; madde hükmündeki inkâr faraziyesini sadece ispat yükü bağlamına hapsetmektedir. Yani davalının cevap vermemiş olması vakıanın inkârı anlamına geleceği için (ispat yükünü taşıyan) davacı yine davasını ispatla mükellef olacak; ancak davacının bu ispat yükünü karşılamış olması halinde davalıya herhangi bir savunma hakkı tanınmamış olacaktır. Böyle bir sonuca varımın, savunma hakkının Kanundaki düzenlenişi bakımından ciddi bir problem yaratacağ 1 kanaatindeyiz. Zira, kanun lafzı ve ruhuyla bir bütün olarak ele alınmalı ve hükümleri buna göre yorumlanmalıdır. Ya davalıya savunma ve inkâr yükü açık şekilde getirilip sessizliğine gerçek anlamda bir yaptırım bağlanmalı ya da 128'inci maddedeki inkâr faraziyesi gerçek anlamda uygulanıp, davalıya genel hükümler çerçevesinde bir savunma imkânı tanınmalıdır.

Cevap dilekçesi vermeme durumu sadece davalıyla ilgili olmakla birlikte, duruşmaya (mazeretsiz şekilde) katılmamaya bağlanan sonuçlar, elbette ki her iki tarafı da ilgilendirmektedir. Kanun koyucunun, 6100 sayılı HMK'nın bu konudaki hükümlerinin kaleme alınmasında büyük ölçüde mülga 1086 sayılı HUMK'un son halinden yararlandığı görülmektedir. Eski kanuna benzer şekilde, usulüne uygun şekilde davet edilmiş olan taraflar, duruşmaya gelmedikleri veya gelip de davayı takip etmeyeceklerini bildirdikleri takdirde dosyanın işlemden kaldırılmasına karar verilir (m. 150/1). Usulüne uygun şekilde davet edilmiş olan taraflardan biri duruşmaya gelir, diğeri gelmezse, gelen tarafın talebi üzerine, yargılamaya gelmeyen tarafin yokluğunda devam edilir veya dosya işlemden kaldırılır. Geçerli bir özrü olmaksızın duruşmaya gelmeyen taraf, yokluğunda yapılan işlemlere itiraz edemez (m. 150/2). Yani Kanun, duruşmaların yapılabilmesi bakımından taraf teşkilini aramamakta, bir tarafın gelmesini (ve davaya devam edeceğini bildirmesini) yeterli görmektedir. Duruşmaya mazeretsiz şekilde gelememe halinin yaptırımı ise

\footnotetext{
${ }^{84}$ Benzer yönde: E. Yılmaz, s. 2907; Akyol Aslan, s. 503; aksi yönde: Pekcanıtez, Pekcanıtez Medeni Usul Hukuku, 15. Bas1, On iki levha, 2017, s. 1206.

85 Bu kararlar için bkz. E. Yılmaz, s. 2905 vd; Pekcanıtez, s. 1203 vd; Akyol Aslan, s. 492 vd.
} 
yok olunan duruşmada yapılan işlemlere itiraz edilememesidir. Bu hüküm, Hükümet gerekçesinde de ifade edildiği üzere, büyük ölçüde, 1985 yılında 3156 sayılı Kanunla gıyap kurumunun kaldırılması ile getirilen HUMK yeni 409'uncu madde hükmünün karşılığıdır ${ }^{86}$. Ancak giyap kurumuna göre çok daha basit olan bu düzenleme çerçevesinde getirilen yaptırımın, dikkatli incelendiğinde gıyap kurumundan aslında daha ağır şekilde düzenlendiği görülmektedir:

Yukarıda da anlattığımız üzere, "glyap kararı verilen celsede muayyen muamelât kısmen veya tamamen ifa olunmuş ise tebliğ varakasında yapılan muamelât yazllip gaibe beş gün içinde itiraz edebileceğgi" bildiriliyordu (mülga HUMK m. 402). Öğreti ve uygulamada muameleli giyap olarak isimlendirilen bu gıyap türünde, hakkında gıyap kararı verilen tarafa bir itiraz hakkı tanınıyordu. Bu itiraz sonunda, tayin olunan günde mahkemede hazır bulunup da giyaben cereyan eden muamelelerin tadil ve cerh ve iptalini mucip bir itiraz dermeyan ettiği takdirde tetkik olunarak varit görülürse kabul ve aksi halde giyaben cereyan eden muameleler muteber addolunuyordu. Oysaki yeni sistemde duruşmalara katılmayan tarafa bir itiraz hakkı tanınmamaktadır. Duruşmada yok olan taraf ancak eski hale getirme hükümlerinde (HMK m. 95 vd.) olduğu gibi katılmamasını haklı gösterecek bir mazerete dayanarak bu işlemlerin ortadan kaldırılmasını sağlayabilir ${ }^{87}$. Yani hukuki dinlenilme hakkına aykırı olduğu ileri sürülmüş olan gıyapta yargılama sisteminde, aslında mevcut sisteme göre daha kuvvetli bir hukuki koruma sağlanmış olduğu söylenebilir.

Her iki tarafın da duruşmaya gelmemiş olması halinde ise dosya işlemden kaldırılır (HMK m. 150). Dosyanın işlemden kaldırılması usulü giyapta yargılama hükümlerinin uygulandığı zamanlarda da, yani HUMK'un orijinal halinde de bulunmaktaydı. Zira bir üst başlıkta da açıkladığımız üzere, gıyap yalnızca taraflardan birisinin gelmemesi halinde uygulanabiliyordu. Tarafların her ikisinin de gelmemiş olması halinde yargılamanın devamı, en azından genel kural olarak, tasarruf ilkesine aykırı olacağı için, dosyanın işlemden kaldırılması kuralı Türk hukuk yargılamasında hep var olan bir kural olmuştur. Dosyanın işlemden kaldırılması meselesi bu makalenin kapsamını

\footnotetext{
${ }^{86} 3156$ say1lı Kanunun Hükümet Gerekçesi: <https://www5.tbmm.gov.tr/tutanaklar/ TUTANAK/TBMM/ d23/c089/tbmm23089050ss0393.pdf>, Erişim tarihi: 09.09.2021.

87 Baki Kuru, Medeni Usul Hukuku El Kitabı, Cilt I, Yetkin, 2020, s. 561.
} 
aştı̆̆ 1 için, bu konunun ayrıntılarına girmiyoruz ${ }^{88}$.

\section{6100 Sayılı Hukuk Muhakemeleri Kanunu'ndaki Konumuz ile Bağlantılı Diğer Hükümler}

Taraflardan birisinin duruşmaya gelmemesi bağlamında 6100 sayılı HMK'da bulunan en ilginç hüküm, hiç kuşkusuz 7251 sayılı Kanun ile değiştirilmeden önceki 139 ve 141'inci maddelerde ön inceleme duruşması bağlamında getirilmiş olan düzenleme idi. 141'inci maddenin orijinal halinde, “... Ön inceleme duruşmasına taraflardan biri mazeretsiz olarak gelmezse, gelen taraf onun muvafakati aranmaksızın iddia veya savunmasını genişletebilir yahut değiştirebilir..." hükmü yer almaktayd. Maddenin Hükümet gerekçesi de bu hükmün gerekliliğini açıkliyordu: "Ön inceleme oturumunun yargllama bakımından önemi sebebiyle, tarafların bu oturuma mümkün olduğunca katılmasını săglamak gereklidir. Bunun için de, gelen tarafi ödüllendirecek, mazereti olmadan gelmeyen tarafi cezalandıracak bir yol izlenmesi zorunludur. Yargılamanın să̆lıkl yürütülmesi ve amacı, tarafların keyfì ve kötüniyetli davranışlarına feda edilmemelidir. Dürüstlük ilkesi de bunu gerektirir. Bu sebeple, her iki taraf da ön inceleme oturumuna gelirse, ancak karşı tarafin muvafakati ile genişletme söz konusu iken; taraflardan biri mazeretsiz gelmez, diğeri gelirse, gelen taraf, karşı tarafin muvafakatine gerek olmadan iddia ve savunmasını genişletip değiştirebilecektir. Bunun en önemli sonucu, uyuşmazlık noktalarının tespit edildiği ön inceleme oturumunda, gelen tarafin daha avantajlı bir konuma sahip olmasıdır. Bundan sonra yürütülecek tartışmada, gelen taraf kendini daha sağlam bir noktaya yerleştirerek hakkını ararken, karşı taraf daha zayıf konuma gelebilecektir." Ancak bu hükmün, ön inceleme duruşmasının varlık amacına aykırı olduğu yönünde de pek çok eleştiri bulunmaktaydi ${ }^{89}$. Kanun koyucu 2020 y1lında 7251 sayılı Kanunla HMK' da yapılan değişiklikle, bu yaptırımdan vazgeçmiş ve yazılı yargılama usulü için, iddianın veya savunmanın değiştirilmesi veya genişletilmesi yasağını, olması gerektiği gibi ikinci dilekçeler aşamasına çekmiştir.

Yukarıda da ifade ettiğimiz üzere, Kanunun bazı maddelerinde, "tarafın yokluğu hakkındaki hükümler”e atıf yapıldığı görülmektedir. 79'uncu maddede, davasını kendisi takip eden kimsenin, duruşmada uygun olmayan

88 Bu konuda ayrıntılı bilgi için bkz. Cumhur Rüzgaresen, Medeni Usul Hukukunda Dosyanın İşlemden Kaldırılması, Yetkin, 2021.

89 Bu eleştiriler hakkında bkz. Mustafa Göksu, “Hukuk Muhakemeleri Kanunu'nun Tadili İhtiyacı ve Bu Konudaki Tasarı Taslağının Değerlendirilmesi”, Ekim 2017, (32), Türkiye Adalet Akademisi Dergisi, s. 78. 
tutum ve davranışta bulunması üzerine mahkemenin kendisini vekil ile temsil ettirmesine karar vermesi ancak tarafin bunu yapmamasi halinde; 80'inci maddede, taraflardan birisinin, davasını bizzat takip edecek yeterlikte olmadığını görürse, hâkimin ona uygun bir süre tanıyarak, davasını vekil aracılığıla takip etmesine karar vermesi ancak tarafin buna uymaması halinde; 82'nci maddede vekilin istifa etmiş olması ve vekâlet verenin davayı takip etmemesi veya başka bir vekil de görevlendirmemesi halinde ve nihayet 83'üncü maddede vekil ile takip edilen davada, vekilin azli hâlinde vekâlet verenin davayı takip etmemesi ve iki hafta içinde bir başka vekil de görevlendirmesi halinde, tarafın yokluğu hâlinde uygulanacak hükümlere göre işlem yapılacağı Kanunda düzenlenmiştir. Ancak yukarıda da ifade ettiğimiz üzere Kanunda, bir tarafin yokluğunda uygulanacak olan hükümler, gıyapta yargılama hükümlerinde olduğu gibi sistematik şekilde düzenlenmemiştir. $\mathrm{Bu}$ sebeple, bu hükümlerden anlaşılması gereken, m. 150/2 hükmü, yani tarafın yokluğunda yapılan işlemlere itiraz edememesi sonucudur ${ }^{90}$. Buna göre, yukarıda bahsettiğimiz hükümlerdeki durumlardan birinin gerçekleşmesi halinde, taraf duruşmaya gelmiş olsa dahi herhangi bir usul işlemi veya açıklama yapmasına izin verilmez ve yapılan işlemlere itiraz edemez. Ancak bu durum, yukarıda gıyapta yargılama usulünde anlattığımız üzere, isticvap veya yemin gibi özel durumlara engel olmamalıdır. Yani hakkında tarafın yokluğundaki hükümlere göre işlem yapılan bir taraf, isticvap veya yemin gibi özel prosedürlere tabi tutulabilir. Ayrıca tarafın yokluğundaki hükümlere tabi olma hali gıyap gibi kurumsal bir usul olmadığı için, taraf mahkemenin isteğini yerine getirip örneğin vekil tayin etmişse, vekil derhal yargılamaya dâhil edilmeli ve tarafin yokluğundaki hükümlerin uygulanmasına son verilmelidir.

Yukarıda ayrıntılı olarak değindiğimiz 128'inci madde hükmü ile davalının sessiz kalmasının inkâr sonucunu doğuracağı Türk hukuku bakımından açıktır. Ancak sessiz kalmanın ikrar olacağı istisnai haller de yine mülga 1086 sayılı HUMK'ta olduğu gibi HMK' da da düzenlenmiștir. Bunlar isticvap ve yemine davet halleridir. Kanunun 171'inci maddesine göre, "isticvabina karar verilen kimseye bizzat davetiye gönderilir ve belirlenen gün ve saatte isticvap olunmak üzere hazır bulunması gerektiği belirtilir. Davetiyede, ayrıca, isticvap konusu vakıalar gösterilir; ilgili tarafin geçerli bir özrü olmaksızın gelmediği veya gelip de sorulara cevap vermediği takdirde, isticvap konusu vakıaları ikrar

90 Murat Atal1/ İbrahim Ermenek/ Ersin Erdoğan, Medeni Usul Hukuku, 4. Bask1, Yetkin, 2021, s. 252. 
etmiş sayılacă̆ ihtarı da yapılır. Çă̆rılan taraf özürsüz olarak gelmediği veya gelip de sorularl cevapsiz bıraktığ takdirde, mahkemece sorulan vakıalar ikrar edilmiş sayılır". Kanunun 229'uncu maddesine göre de "yemin için davet edilen kimse, tayin edilen gün ve saatte mahkemede geçerli bir özrü olmaksızın bizzat hazır bulunmaz yahut hazır bulunup da yemini iade etmez ya da yemini eda etmekten kaçınırsa yemin konusu vakıaları ikrar etmiş sayılır." Ayrıca kendisine yemin iade olunan kimse, yemin etmekten kaçınırsa yemin konusu vakıa ispat edilememiş sayılır. Bu iki hüküm de hiç kuşkusuz hem davacı hem de davalı bakımından uygulanabilir. Bu iki halden birisinin varlığı halinde, ilgili taraf duruşmaya gelmez veya gelip de sorulan soruları cevaplamaz ya da kendisine teklif edilen yemini eda etmezse aleyhine ileri sürülmüş olan ve isticvabın veya yeminin konusunu oluşturan vakıa ya da vakıaları ikrar etmiş sayılır.

Kanunun bölge adliye mahkemelerinde tahkikatı düzenleyen maddelerinden olan (7251 sayılı Kanunla değişik) 358'inci madde ile ilk derece mahkemelerindeki konumuzla ilgili olarak genel kuraldan (HMK m. 150) sapıldığı görülmektedir. Buna göre, "duruşmalı olarak incelenen işlerde taraflara çıkartılan davetiyelerde, duruşmada hazır bulunmadıkları takdirde tahkikatın yokluklarında yapılarak karar verileceği hususu ile başvuran tarafa çıkartılacak davetiyede, ayrıca, yapılacak tahkikatla ilgili olarak bölge adliye mahkemesince belirlenen gideri, iki haftadan az olmamak üzere verilecek kesin süre içinde avans olarak yatırması gerektiği" açıkça belirtilir. Başvuran, kabul edilebilir bir mazerete dayanarak duruşmaya gelemediğini bildirdiği takdirde, yeni bir duruşma günü tayin edilerek taraflara bildirilir." Bu hakkın, eşitlik ilkesi gereği, başvurunun karşı tarafı için de geçerli olduğu kabul edilmelidir ${ }^{91}$. Belirlenen giderin, verilen kesin süre içinde yatırılmış olması kaydıyla, taraflar mazeretsiz olarak duruşmaya katılmadıkları takdirde tahkikat yokluklarında yapılarak karar verilir. Belirlenen gider, süresi içinde yatırılmadığı takdirde, dosyanın mevcut durumuna göre karar verilir. Bununla birlikte, öngörülen tahkikat yapılmaksızın karar verilmesine olanak bulunmayan hâllerde başvuru reddedileceği düzenlenmiştir. Yani bölge adliye mahkemesinde genel kural, istisnaları bulunmakla birlikte, tarafların yokluğunda tahkikatın yürütülmesinin esas olmasıdır.

İstinaftaki duruşmalara ek olarak, Kanunda ayıca diğer bazı hallerde de taraflar gelmese dahi işlemlerin yapılacağı minvalinde hükümler de

91 Selçuk Öztek, Türk Medeni Yargılama Hukukunda İstinaf ve Temyiz, Yetkin, 2021, s. 428, $\S 276$, dn. 3 . 
bulunmaktadır. Örneğin ihtiyati tedbir talebinin incelenmesinde (HMK m. 390), feri müdahale talebinde (HMK m. 67/2); Temyiz incelemesinde (HMK m. 369/5) benzer hükümler yer almaktadır ${ }^{92} 7251$ sayılı Kanunla değiştirilmeden önce, sözlü yargılama ve hüküm aşamasına ilişkin olarak da özel bir hüküm bulunmaktaydı. 186'ncı maddenin eski hali, "mahkeme, tahkikatın bitiminden sonra, sözlü yargılama ve hüküm için tayin olacak gün ve saatte mahkemede hazır bulunmalarını sağlamak amacıyla iki tarafı davet eder. Taraflara çıkartılacak olan davetiyede, belirlenen gün ve saatte mahkemede hazır bulunmadıkları takdirde yokluklarında hüküm verileceği hususu bildirilir." şeklinde idi. Bu durumda iki tarafin gelmemesi halinde dosya işlemden kaldırılamıyordu ${ }^{93}$. Ancak 7251 sayılı Kanunla maddenin ikinci fikrasının sonuna "Şu kadar ki, 150 nci madde hükmü saklıdır." cümlesi eklenmiştir. Bu sebeple dosyanın işlemden kaldırılması bağlamında, sözlü yargılama duruşması, artık tahkikat duruşması gibi değerlendirilecek ve 150'nci madde hükmü uygulanacak; yani her iki tarafın yokluğunda hüküm verilmesi mümkün olmayacaktır.

Bir üst başlıkta ifade ettiğimiz üzere, Amerikan hukukundaki gıyapta hüküm sisteminde, duruşma öncesi usullerde, delillerin toplanması bağlamında mahkemenin verdiği talimatların gereğini yerine getirmeyen taraflar ile ilgili olarak da gıyapta hüküm kurumunun işletilebilmesi mümkündür. Bununla bağlantılı olarak hukukumuzda da benzer bir usul bulunmaktadır. Usul kanunumuzun 219'uncu maddesi ile tarafların, kendilerinin veya karşı tarafın delil olarak dayandıkları ve ellerinde bulunan tüm belgeleri mahkemeye ibraz etmeleri zorunlu kılınmıştır. 220'nci maddeye göre de mahkeme bir belgenin ibrazı istendiğinde, bu belgenin, ileri sürülen hususun ispatı için zorunlu ve bu isteğin kanuna uygun olup olmadığını inceler. Karşı taraf bu belgenin elinde olduğunu ikrar eder veya ileri sürülen talep üzerine sessiz kalır yahut belgenin var olduğu resmî bir kayıtla anlaşılır veya başka bir belgede ikrar edilirse, mahkeme ilgili tarafa bu belgenin ibrazı için kesin bir süre verir. Mahkeme ayrıca, ibrazı istenen belgenin elinde bulunduğunu inkâr eden tarafa, böyle bir belgenin elinde bulunmadığına, özenle aradığı hâlde bulamadığına ve nerede olduğunu da bilmediğine ilişkin yemin teklif eder. Belgenin sunulmamasının yaptırımı da yine 220'nci maddenin son fikrasında düzenlenmiştir. Buna göre,

92 Rüzgaresen, s. 223 vd.

93 Ramazan Arslan/ Ejder Yılmaz/ Sema Taşpınar-Ayvaz/ Emel Hanağası, Medeni Usul Hukuku, 6. Bask1, Yetkin, 2020, s. 473; Süha Tanrıver, Medeni Usul Hukuku, Cilt I, Yetkin, 2016, s. 701-702. 
"Belgeyi ibraz etmesine karar verilen taraf, kendisine verilen sürede belgeyi ibraz etmez ve ayn sürede, delilleriyle birlikte ibraz etmemesi hakkında kabul edilebilir bir mazeret göstermez ya da belgenin elinde bulunduğunu inkâr eder ve teklif edilen yemini kabul veya icra etmezse, mahkeme, duruma göre belgenin içeriği konusunda diğer tarafin beyanını kabul edebilir." Benzer bir hüküm, ticari defterlerle ilgili olarak 222. maddede de bulunmaktadır ${ }^{94}$. Görüldüğü üzere bizim sistemimizde de Amerikan hukukundakine benzer bir yaptırım bulunmaktadır. Ancak aradaki temel fark, bizim hukukumuzda yargılamaya devam edilip, bahsi geçen hükmî "ikrar" sonucu, hüküm faaliyeti sırasında değerlendirilmekte, Amerikan hukukunda ise duruşmalar aşaması hiç gerçekleştirilmeyip doğrudan hüküm kurulmaktadır.

Yine bazı özel kanunlarda da duruşmaya katılmamanın yaptırımları düzenlenmiş olabilir. Örneğin 2004 say1lı İcra ve İflas Kanunu'nun 68/a maddesinin ikinci fikrasına göre, "senet altındaki imzayı reddeden borçlu takibi yapan icra dairesinin yetki çevresi içinde ise, itirazın kaldırılması için icra mahkemesi önünde yapılacak duruşmada, mazeretini daha önce bildirip tevsik etmediği takdirde, bizzat bulunmaya mecburdur. İcra dairesinin yetki çevresi dışında ödeme emri tebliğ edilen borçlu, istinabe yolu ile isticvabına karar verilmesi halinde, aynı mecburiyete tabidir."; yine aynı Kanunun 68'inci maddesinin altınc1 fikrasına göre, "alacaklı duruşmada bizzat bulunmayıp da imza vekili tarafindan reddolunduğu takdirde vekil mütaakı oturumda müvekkilini imza tatbikatı için hazır bulundurmaya veya masraflarını vererek davetiye tebliğ ettirmeye mecburdur. Kabule değer mazereti olmadan gelmiyen alacaklı borçlunun dayandiğı belgede yazılı miktar hakkındaki itirazın kaldırılması talebinden vazgeçmiş sayılır." Diğer bir örnek olarak 3402 sayılı Kadastro Kanunu'nun 29'uncu maddesi gösterilebilir. Maddeye göre, "Kadastro mahkemesinde gelmeyen tarafin yokluğunda duruşma yapılır. Taraflardan hiç biri gelmez ise dosya işlemden kaldırılmaz. Hakim, toplanması mümkün olan delilleri inceler ve 30 uncu madde hükmünce işi karara bağlar." Görüldüğü üzere Kanun koyucu bazı yargılama türleri bakımından, yapılan incelemenin niteliğine göre, tarafların birisinin veya her ikisinin gelmemesine HMK m. 150'deki genel hükümden ayrılarak farklı sonuçlar bağlamıştır.

94 Belgenin karşı tarafça ibrazı konusu ile ilgili olarak bkz. Güray Erdönmez, Medeni Usul Hukukunda Belgelerin İbrazı Mecburiyeti, 2. Bask1, On iki levha, 2014; Mustafa Göksu, "Hukuk Yargılamasında Karşı Tarafın Elindeki Belgelere Delil Olarak Başvurulabilmesi", 2009/2, Say1 13, Legal Medeni Usul ve İcra - İflas Hukuku Dergisi, s. 251-282. 
Türk Hukuk Yargılaması İle Mukayeseli Olarak Amerikan Hukuk...

\section{SONUÇ}

Her hukuk sistemi tüm kurumlarıyla birlikte bir bütün olarak düşünülmeli ve bu hukuk sistemindeki kanunlar bu şekilde hazırlanmalıdır. Bir hukuk sisteminin içinde veya bir hukuk sistemindeki bir hukuk dalının içinde birbiriyle çelişen kurumlar olması, bu kurumların düzgün şekilde işleyememesinin yanı sıra toplumda hukuka olan güvenin sarsılmasına da neden olur. Meseleye bu çerçeveden bakıldığında, eskiden hukukumuzda uygulanan gıyapta yargılama kurumunun da özünde faydalı bir kurum olmakla birlikte, Kanununun geri kalanıyla çok uyumlu olmadığ 1 için başarıya ulaşamamış olduğu görülmektedir. Özellikle başka ülkelerin hukuk sistemlerinden alınan kurumların, ülke hukukuna entegre edilmesi çok zor olduğu için, bu kurumların Kanunun bütünü gözetilerek kaleme alınması çok büyük önem taşımaktadır. Gıyapta yargılama usulünün kendisi, adil yargılanma veya hukuki dinlenilme hakkı gibi temel Anayasal haklarla doğrudan bağlantılı değildir. Bu ilkelerle bağlantılı olan, usulün düzenlenme şeklidir. Nitekim buna benzer kurumlar, Almanya, İngiltere ve ABD gibi ülkelerde başarılı şekilde uygulanmaktadır. Özellikle tarafların ve vekillerin dürüst davranma ve doğruyu söyleme yükümlülüğü ve usul ekonomisi gibi ilkeler gözetildiğinde, gıyapta yargılama benzeri kurumların çok faydalı olduğu da görülmektedir. Haklı bir mazereti olmaksızın davaya hiç cevap vermeyen veya davayı takip etmeyen bir davalının, davaya cevap veren ve davayı takip eden davalı ile aynı hükümlere tabi kılınması, hukuki dinlenilme hakkının değil, bu yöndeki hukuk politikası kararının bir sonucudur. Nitekim Türk Kanun koyucusu da bu bağlamda davalıya bu şekilde bir yük yüklememiş ve her iki taraf bakımından da gıyapta yargılama kuruma ihtiyaç duymamıştır.

Buna karşı1ık Amerikan hukuk yargılamasında haklı bir mazereti olmaksızın davaya cevap vermeyen veya davayı takip etmeyen davalı ya da mahkemece verilen talimatları yerine getirmeyen taraflar hakkında, bazı yaptırımlar düzenlenmiştir. Bu yaptırımların uygulanması ise bazı şartlara bağlanmış ve bunların olası zararlarını ortadan kaldıracak çeşitli hukuki çareler de öngörülmüştür. Kanaatimizce gıyapta hüküm kurumu, tıpkı eskiden hukukumuzda olan giyapta yargilama kurumu gibi son derece faydalı ve tarafları iş birliğine sevk eden, onların dürüst davranma ve doğruyu söyleme yükümlülüklerini pekiştiren ve bu çerçevede usul ekonomisi ilkesine katk1 sağlayan bir kurumdur. Türk mahkemelerinin daha sağlılı ve etkin işleyebilmesi için, tarafları mahkeme ile iş birliği yapmaya teşvik eden benzer bir kurumun Türk hukuk yargısına daha etkin bir şekilde yeniden kazandırılması kanaatimizce son derece faydalı olacaktır. 


\section{KAYNAKÇA}

Abernathy C F, Law in the United States, International Law Institute, 1995.

Akyol Aslan L, Medeni Usul Hukukunda Cevap Dilekçesi Verilmemesinin Sonuçları, Yetkin, 2019.

Alangoya Y, Medeni Usul Hukukunda Vakıaların ve Delillerin Toplanmasına İlişkin İlkeler, Fakülteler Matbaası, 1979.

Ansay S Ş, Hukuk Yargılama Usulleri, Yedinci Bask1, Güzel Sanatlar Matbaası, 1960.

Arslan R / Yılmaz E / Taşpınar- Ayvaz S / Hanağası E, Medeni Usul Hukuku, 6. Bask1, Yetkin, 2020.

Arslan R, Medeni Usul Hukukunda Dürüstlük Kuralı, S Yayınları, 1989.

Atalı M / Ermenek İ / Erdoğan E, Medeni Usul Hukuku, 4. Baskı, Yetkin, 2021.

Belgesay M R, Hukuk Usulü Muhakemeleri Kanunu Şerhi, Teoriler, 3. Bas1, Duygu Matbaas1, 1948.

Bilge N / Önen E, Medeni Yargılama Hukuku Dersleri, Üçüncü Baskı, Sevinç Matbaas1, 1978.

Börü L, Medeni Usul Hukukunda İddia ve Somutlaştırma Yükü, Yetkin, 2016.

Bresnan P H / Cornelio J P, "Relief from Default Judgments Under Rule 60(b)-A Study of Federal Case Law", 1981, 49(6), Fordham Law Review, s. 956-1011.

Budak A C / Karaaslan V, Medeni Usul Hukuku, 4. Bask1, Adalet, 2020.

Doğan M, Hukuk Muhakemeleri Usulünde Giyapta Yargilama ve Dosyanın İşlemden Kaldırılması, Yargıcıoğlu Matbaası, 1979.

Donald B B / Cooper K J, "Collateral Estoppel In Section 523(C) Dischargeability Proceedings: When Is A Default Judgment Actually Litigated?", 1996, (12), Bankruptcy Developments Journal, s. 321-353.

Erdönmez G, Medeni Usul Hukukunda Belgelerin İbrazı Mecburiyeti, 2. Bask1, On iki levha, 2014.

Ermenek İ, Medeni Usul Hukukunda Davaların Birleştirilmesi ve Ayrılması, 
Türk Hukuk Yargılaması İle Mukayeseli Olarak Amerikan Hukuk...

Yetkin, 2014.

Field R H / Kaplan B / Clermont K M, Civil Procedure, Foundation Press, 1997.

Göksu M, “Hukuk Muhakemeleri Kanunu’nun Tadili İhtiyacı ve Bu Konudaki Tasarı Taslağının Değerlendirilmesi”, Ekim 2017, (32), Türkiye Adalet Akademisi Dergisi, s. 61-93.

Göksu M, "Hukuk Yargılamasında Karşı Tarafin Elindeki Belgelere Delil Olarak Başvurulabilmesi”, 2009/2, (13), Legal Medeni Usul ve İcra İflas Hukuku Dergisi, s. 251-282.

Hanağası E, Hukuk Usulü Muhakemeleri Kanunu'nun Tarihsel Gelişimi, Yayınlanmamış Yüksek Lisans Tezi, Ankara, 2001.

Hanağası E, Medeni Yargılama Hukukunda Silahların Eşitliği, Yetkin, 2016.

Hazard JR G C / Taruffo M, American Civil Procedure, Yale University Press, 1993.

Hensler D R, "USA National Report", in C. Hodges, S. Vogenauer, M. Tulibacka (eds.), The Costs and Funding of Civil Litigation, Hart/Beck, 2010, s. 535-544.

Holleman J T IV, “Revised Rule 55 Revisited.” Spring 1999, 21(3), University of Arkansas at Little Rock Law Review, s. 443-454.

James F / Hazard G C / Leubsdorf J, Civil Procedure, 5th Edition, Foundation Press, 2001.

Kaplan B / Clermont M, "Chapter 6: Ordinary Proceedings in First Instance", M. Cappalletti (ed), International Encyclopedia of Comparative Law, Volume XVI: Civil Procedure, Mohr Siebeck, 2014, s. 1-82.

Kay Kane M, Civil Procedure in a Nutshell, West, 1996.

Kerley P / Banker Hames J / Sukys P A, Civil Litigation, 6th Edition, Delmar, 2012.

Kuru B / Yılmaz E, "1711 Sayılı Kanuna Göre Gıyap ve Dosyanın İşlemden Kaldırılmas1 Rejimi”, Makaleler (1973-2013), 1. Cilt, Yetkin, 2014, s. 147-176.

Kuru B, Medeni Usul Hukuku El Kitab1, Cilt I, Yetkin, 2020. 
Levasseur E B, "Default Judgments: Strategies for Making Them Stick and for Making Them Go Away", Fall 2015, 42(1), Litigation, s. 45-52.

Maxeiner J, "The American 'Rule': Assuring the Lion His Share", in M. Reimann (ed.), Cost and Fee Allocation in Civil Procedure, Springer, 2012, s. 287-303.

Miller S J, "Misnomers: Default Judgments and Strict Compliance with Service of Process Rules." 46(3), Summer 1994, Baylor Law Review, s. 633-652.

Önen E, Medeni Yargılama Hukuku, Sevinç Matbaası, 1979.

Özekes M, Medeni Usul Hukukunda Hukuki Dinlenilme Hakk1, Yetkin, 2003.

Öztek S, Türk Medeni Yargılama Hukukunda İstinaf ve Temyiz, Yetkin, 2021.

Palmer E L, "Service by Certified Mail Insufficient to Preserve Default Judgment”, 40(4) Litigation News, s. 18.

Panoff J N, "Debtors, Creditors, Default Judgments, \& Discretion: Why Rule 62(b)(4) Will Become One of the Most Important Federal Rules of Civil Procedure", Summer 2015, 44(1), 2010, Creighton Law Review, s. 227260.

Papakçı A, "Alman Mahkemelerince Verilen Giyabi Kararların Yargılama ve Uluslararası Tebligat Kuralları Açısından Türk Hukukuna Uygunluğu", 2016, 22(1), Marmara Üniversitesi Hukuk Fakültesi Hukuk Araştırmaları Dergisi, s. 457-487.

Park A J, "Fixing Faults in the Current Default Judgment Framework", Fall 2011, 34(1), Campbell Law Review, s. 155-180.

Pekcanıtez H, "Hukuki Dinlenilme Hakkı", Makaleler, C. 1, On iki levha, 2016, s. 509-559.

Pekcanıtez H, Pekcanıtez Medeni Usul Hukuku, 15. Bası, On iki levha, 2017.

Pendrey J F, "Dealing with Default Judgements", 2003, 35(1), St. Mary's Law Journal, s. 1-92.

Peterson T D, "The Misguided Law of Compulsory Counterclaims in Default Cases", 2008, 50(4), Arizona Law Review, s. 1107-1146.

Pohl M A, "Judgments by Default in Texas", 1983, 37(2), SMU Law Review, 
s. $421-460$.

Postacıoğlu İ E, Medeni Usul Hukuku Dersleri, Altıncı Bas1, Sulhi Garan Matbaas1, 1975.

Rogers H L, "Process Sufficient to Require a Defense or Default Judgment", August 1959, 30(4), Mississippi Law Journal, s. 388-412.

Rosenberg M / Smit H / Cooper Dreyfuss R, Elements of Civil Procedure, Fifth Edition, Foundation Press, 1990.

Rüzgaresen C, Medeni Usul Hukukunda Dosyanın İşlemden Kaldırılması, Yetkin, 2021.

Tanrıver S, Medeni Usul Hukuku, Cilt I, Yetkin, 2016.

Teply L L / Whitten R U, Civil Procedure, Fourth Edition, Foundation Press, 2009.

Ulukapı Ö, "Medeni Usul Hukukunda Davada Bir Tarafın Duruşmaya Gelmemesi”, 1988, (1), SÜHFD, s. 171-188.

Umar B, "Hukuk Muhakemeleri Kanunu Tasarısına Katk1", 2006, (57), TBB Dergisi, s. 121-162.

Ünal S M, "Hukuk Muhakemeleri Usulünde Giyap”, 1965, (5), Ankara Barosu Dergisi, s. 569-573.

Üstündağ S, Medeni Yarg1lama Hukuku, Cilt I-II, 6. Bası, Alfa, 1997.

Wagstaff J S, "California's Default and Default Judgment: A Procedural and Substantive Review", 1988, (15), Western State University Law Review, s. $679-757$.

Watkins J J, “Revised Rule 55, Five Years Later”, 1996-1997, 49(1), Arkansas Law Review, s. 23-82.

Y1lmaz E, Hukuk Muhakemeleri Kanunu Şerhi, 3. Cilt, 4. Baskı, Yetkin, 2021.

Y1lmaz O, “Adi ve Muameleli Giyap Hakkında Bir İnceleme”, Aralık 1972, (12), Adalet Dergisi, s. 907-919. 